\title{
Perturbation of the European free troposphere aerosol by North American forest fire plumes during the ICARTT-ITOP experiment in summer 2004
}

\author{
A. Petzold ${ }^{1}$, B. Weinzierl ${ }^{1}$, H. Huntrieser ${ }^{1}$, A. Stohl ${ }^{2}$, E. Real ${ }^{3}$, J. Cozic ${ }^{4}$, M. Fiebig ${ }^{1}$, J. Hendricks ${ }^{1}$, A. Lauer ${ }^{1}$, \\ K. Law $^{3}$, A. Roiger ${ }^{1}$, H. Schlager ${ }^{1}$, and E. Weingartner ${ }^{4}$ \\ ${ }^{1}$ Institut für Physik der Atmosphäre, Deutsches Zentrum für Luft- und Raumfahrt, 82234 Wessling, Germany \\ ${ }^{2}$ Norwegian Institute for Air Research (NILU), P.O. Box 100, 2027 Kjeller, Norway \\ ${ }^{3}$ CNRS Service Aeronomie, Universite Pierre et Marie Curie. 4 Place Jussieu, 75252 Paris Cedex 05, France \\ ${ }^{4}$ Laboratory of Atmospheric Chemistry, Paul Scherrer Institute, 5232 Villigen PSI, Switzerland
}

Received: 5 March 2007 - Published in Atmos. Chem. Phys. Discuss.: 10 April 2007

Revised: 7 September 2007 - Accepted: 16 September 2007 - Published: 4 October 2007

\begin{abstract}
During the ICARTT-ITOP Experiment in summer 2004 plumes from large wildfires in North America were transported to Central Europe at 3-8 km altitude above sea level (a.s.l.). These plumes were studied with the DLR (Deutsches Zentrum fuer Luft- und Raumfahrt) research aircraft Falcon which was equipped with an extensive set of in situ aerosol and trace gas instruments. Analyses by the Lagrangian dispersion model FLEXPART provided source regions, transport times and horizontal extent of the fire plumes. Results from the general circulation model ECHAM/MADE and data from previous aerosol studies over Central Europe provided reference vertical profiles of black carbon (BC) mass concentrations for year 2000 conditions with forest fire activities below the long-term average. Smoke plume observations yielded a BC mass fraction of total aerosol mass with respect to PM 2.5 of $2-8 \%$. The ratio of $\mathrm{BC}$ mass to excess $\mathrm{CO}$ was $3-7.5 \mathrm{mg} \mathrm{BC}(\mathrm{g} \mathrm{CO})^{-1}$. Even after up to 10 days of atmospheric transport, both characteristic properties were of the same order as for fresh emissions. This suggests an efficient lifting of $\mathrm{BC}$ from forest fires to higher altitudes with only minor scavenging removal of particulate matter. Maximum aerosol absorption coefficient values were $7-8 \mathrm{Mm}^{-1}$ which is about two orders of magnitude above the average European free tropospheric background value. Forest fire aerosol size distributions were characterised by a strong internally mixed accumulation mode centred at modal diameters of $0.25-0.30 \mu \mathrm{m}$ with an average distribution width of 1.30. Nucleation and small Aitken mode particles were almost completely depleted.
\end{abstract}

Correspondence to: A. Petzold

(andreas.petzold@dlr.de)

\section{Introduction}

The global climate forcing by black carbon (BC) is still uncertain in magnitude. Estimates range from 0.1 to $0.5 \mathrm{~W} \mathrm{~m}^{-2}$ (Sato et al., 2003). One important source of uncertainties is the limited knowledge on BC source strengths and removal mechanisms. In particular, the long-range transport of $\mathrm{BC}$ from boreal or temperate forest fires suffers from a lack of knowledge on the removal and transformation processes of particles during transport. It is, however, widely accepted that long-range transport is one of the most important factors which controls the spatial and temporal variability of aerosol properties and atmospheric particle load from regional to continental scales across the entire tropospheric column. Although a large fraction of the aerosol remains in the continental or marine boundary layer (CBL, MBL), particularly forest fire plumes may be lifted into the free troposphere (FT) or even into the upper troposphere/lowermost stratosphere (UT/LS) by pyro-convection or radiatively-driven convection (Fromm et al., 2000, 2005; Jost et al., 2004; Damoah et al., 2006) and transported over long distances (Clarke et al., 2007) up to a hemispheric scale (Damoah et al., 2004; Mattis et al., 2003; Müller et al., 2005).

According to van der Werf et al. (2004, 2006), the boreal fire activities over North America were very strong in 1998 and 2004 and very weak in 2000 and 2001. For the 1998 burning season, Spichtinger et al. (2004) investigated the effect of the fire emissions by means of the Lagrangian particle dispersion model FLEXPART (Stohl et al., 2005) and products from spaceborne sensors like the TOMS aerosol index and GOME data. They report distinct anomalies in $\mathrm{CO}$ over Europe while the modification of the tropospheric aerosol

Published by Copernicus Publications on behalf of the European Geosciences Union. 
away from the source regions was not investigated in this study. The impact of wildfire emissions in Russia and Eastern Europe in 2002 on the PM2.5 aerosol load over Finland was discussed by Niemi et al. (2005). The authors reported an increase of particle number concentrations in the diameter range $90-500 \mathrm{~nm}$, but a decrease of Aitken and nucleation mode particles with $D_{p}<90 \mathrm{~nm}$.

Transport processes and particle properties of the North American forest fire plumes from August 1998 were intensely studied by several groups. Forster et al. (2001) focused on transport processes and reported pronounced haze layers and considerably enhanced $\mathrm{CO}$ mixing ratios above Europe after an average transport time of $\cong 7$ days from the source regions in Alaska and Canada. As part of the German Lindenberg Aerosol Characterisation Experiment LACE 98, Petzold et al. (2002) and Fiebig et al. (2002) studied a boreal forest fire smoke plume, which was transported from the Northwest Territories, Canada, to Central Europe within about 6 days. They observed a pronounced accumulation mode at $340 \mathrm{~nm}$ in diameter, and absorption coefficients $(\lambda=550 \mathrm{~nm})$ of up to $20 \mathrm{Mm}^{-1}$. In a succeeding study, Fiebig et al. (2003) demonstrated that aerosol ageing processes during transport may increase the solar radiative forcing of the plume by $20-40 \%$. Similar investigations were also conducted for black carbon from biomass burning emissions over the Pacific (Clarke et al., 2001), and in the outflow of Southeast Asia (e.g., Clarke et al., 2004). In a very recent publication Clarke et al. (2007) report results from forest fire plumes studies over the Atlantic Ocean during the ICARTT experiment.

Observations and modelling efforts have demonstrated that long-range and even hemispheric-scale transport of forest fire smoke plumes frequently occurs in the atmosphere. It influences atmosphere's chemical composition, modifies the aerosol properties, and may cause significant effects on the radiative transport through the atmosphere and thus on climate. For instance, the smoke can lead to a significant cooling at the surface (Robock, 1991). Although BC from extratropical biomass burning contributes only $2.9 \%$ to the global annual BC emissions (Streets et al., 2004) its effects on atmospheric radiative properties can be significant from regional (Hsu et al., 1999; Stohl et al., 2006) to almost hemispheric (Fiebig et al., 2003; this paper) scales. Additional to these direct radiative effects, $\mathrm{BC}$ from industrial sources as well as from forest fires may suppress rainfall and modify the hydrological cycle (e.g., Rosenfeld, 2000; Andreae et al., 2004). For the quantification of the radiative forcing due to aerosols, for the assessment of heterogeneous processes with respect to atmospheric chemical composition changes, and for the validation of aerosol products from space-borne sensors such as aerosol optical depth, information on the effects of transformation and mixing processes on forest fire aerosol properties during long-range transport is urgently needed.

The fire season of summer 2004 set a new record of 2.7 million hectare burnt in Alaska and 3.1 million hectare burnt in Canada (Stohl et al., 2006; Pfister et al., 2006) which is more than 10 times as much as the long-term average. For the boreal regions of North America, van der Werf et al. (2006) estimated an annually averaged carbon emission of $90 \mathrm{Tg} \mathrm{C}$ (particulate plus gaseous carbonaceous compounds) which is close to the maximum value of $93 \mathrm{Tg} \mathrm{C} \mathrm{yr}^{-1}$ for the 1998 fire season in North America. The long-range transport of particles emitted during the fire season 2004 significantly modified the aerosol loading of the free troposphere (Damoah et al., 2006) and enhanced UT/LS (upper troposphere/lowermost stratosphere) aerosol extinction by a factor of four relative to conditions almost unperturbed by strong fire plumes. During this burning season the station Barrow, Alaska, which is approximately $1000 \mathrm{~km}$ away from the source, was affected by several smoke plumes with one leading to an aerosol absorption coefficient of $32 \mathrm{Mm}^{-1}$ and an estimated aerosol optical depth (AOD) of 4-5 (Stohl et al., 2006). However, forest fire smoke plumes affect atmospheric conditions not only by adding particulate matter but also by modifying atmospheric chemistry. Measurements in one smoke plume in summer 2004 showed an ozone increase of $17 \mathrm{ppbv}$ over 5 days together with a significant decrease in CO (Real et al., 2007). Following Pfister et al. (2006), the fires increased the ozone burden near the surface over Alaska and Canada during summer 2004 by about 7-9\% and over Europe by about $2-3 \%$.

As a fortunate coincidence in summer 2004 the experiment on the Intercontinental Transport of Ozone and Precursors (ITOP) was conducted over Europe. ITOP formed the European part of the International Consortium on Atmospheric Research on Transport and Transformation (ICARTT) experiment with its main emphasis on pollutant outflow from the US East coast towards the Atlantic Ocean. As part of the ICARTT-ITOP field study, the IGAC Lagrangian 2K4 experiment was performed with its aim of making several samplings in pollutant plumes transported across the North Atlantic. Airborne in situ measurements on aerosols and trace gases were performed by means of the German Falcon 20 E5 research aircraft at the European west coast. Whereas during the LACE 98 study in 1998, one single North American forest fire plume was sampled by lucky coincidence, in the course of the ICARTT-ITOP 2004 study systematic investigations of forest fire plume properties were possible. As one of the most important improvements compared to the 1998 studies an extensive combination of aerosol and trace gas instruments was operated on board of the Falcon so that for the 2004 plumes aerosol microphysics, aerosol optics, excess $\mathrm{CO}, \mathrm{NO}_{\mathrm{y}}$, and $\mathrm{O}_{3}$ data are available. In addition to the airborne in-situ data, data from two long-term monitoring ground sites in Central Europe (Hohenpeissenberg Observatory: $989 \mathrm{~m}$ a.s.l., $47^{\circ} 48^{\prime} \mathrm{N}, 11^{\circ} 0^{\prime} \mathrm{E}$; Jungfraujoch $\mathrm{Ob}-$ servatory: $3580 \mathrm{~m}$ a.s. $1 ., 46^{\circ} 33^{\prime} \mathrm{N}, 7^{\circ} 59^{\prime} \mathrm{E}$ ) were used to investigate the influence of the forest fire smoke plumes on the aerosol properties in the FT and CBL of Central Europe and to estimate the conditions of the European FT aerosol in the 
absence of strong forest fire plumes which defined a kind of reference "background" state. Model results using the ECHAM/MADE global climate model (Lauer et al., 2005) added a further view on the European BC background conditions. FLEXPART data (Stohl et al., 2005) were used to identify fire plumes and to estimate their transport times.

The observations of summer 2004 smoke plumes are presented and discussed in this paper. From the extensive data set, we quantify the perturbation of free tropospheric aerosol above Europe by forest fire smoke plumes from North America. Particular emphasis is put on the BC load, aerosol size distributions and optical properties, and particle removal processes during long-range transport. Modifications of aerosol properties during transport are discussed on the basis of recent emission data on chemical species (Martins et al., 1996; Andreae and Merlet, 2001) and particle microphysical and optical properties for fresh and aged smoke plumes (Reid et al., 2005a, b; Dentener et al., 2006). Effects of the Summer 2004 forest fire smoke plumes on photochemistry are discussed by Real et al. (2007).

\section{Methods}

\subsection{The ITOP study - research flights}

From 19 July to 3 August 2004 a set of research flights was conducted in the framework of the ICARTT-ITOP study. The German Falcon 20 E-5 research aircraft was operating from the airport of Creil $\left(49^{\circ} 15.6^{\prime} \mathrm{N}, 2^{\circ} 31^{\prime} \mathrm{E}\right)$ north of Paris in France. Measurement flights were performed near the European west coast probing the entire tropospheric column from the boundary layer to the upper free troposphere at about $11 \mathrm{~km}$ a.s.l. Figure 1 gives an overview over all performed research flights. The symbols indicate forest fire smoke plume encounters. Additional to the Falcon operation bases Oberpfaffenhofen (OP) and Creil, the mountain observatories Jungfraujoch (JFJ) in the Swiss Alps and Hohenpeissenberg (HP) in Bavaria, Germany, are marked. Table 1 summarises information on the conducted research flights. The areas in which forest fore smoke plumes were traversed are given as average latitude/longitude coordinates of the plume profile.

On board of the DLR research aircraft Falcon, a comprehensive set of instruments was operated for the in situ measurement of aerosol microphysical properties and trace gas mixing ratios, see Table 2 for details. In summary, the aerosol instrumentation consisted of six Condensation Particle Counters (CPC) set to different lower cut-off diameters (Schröder and Ström, 1997), Diffusion Screen Separators (Feldpausch et al., 2006), one Differential Mobility Analyser (DMA), one thermodenuder with two channels set to $20^{\circ} \mathrm{C}$ and $250^{\circ} \mathrm{C}$ (e.g., Engler et al., 2006), two optical particle counters of types Passive Cavity Aerosol Spectrometer Probe (PCASP 100X) and Forward Scattering Spectrometer Probe (FSSP

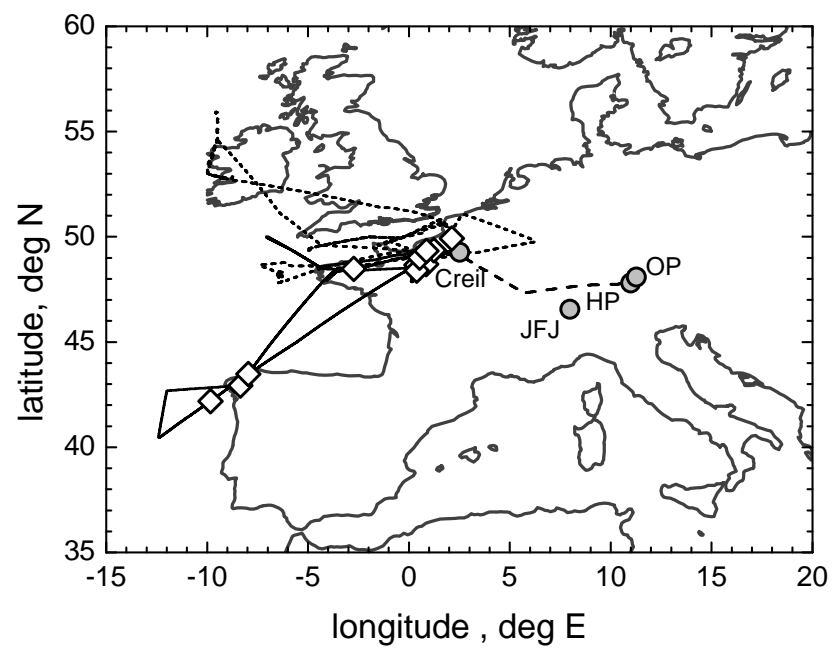

Fig. 1. Map of ITOP flights and measurement sites: Oberpfaffenhofen (home base DLR Falcon), OP; Creil (operation base ITOP); Hohenpeissenberg, HP; Jungfraujoch JFJ; open diamonds represent forest fire smoke plume encounters. Performed flights are grouped according to 19 July (dashed), 22-23 July (solid), 25 July, and 26, 30 , and 31 July (short dashed).

300), and one Particle Soot Absorption Photometer (PSAP; Bond et al., 1999).

The combination of CPC and Diffusion Screen Separators with a DMA instrument and several optical particle spectrometers covered the entire size range from smallest particles in the nucleation mode $\left(D_{p}<0.01 \mu \mathrm{m}\right)$ to coarse mode particles in the far super-micron size range. The probed size range included optically active background Aitken and accumulation mode particles $\left(0.05 \mu \mathrm{m}<D_{p}<1-2 \mu \mathrm{m}\right)$, coarse mode dust or sea salt particles $\left(D_{p}>1 \mu \mathrm{m}\right)$ and particle sizes relevant for particle formation processes $\left(D_{p}<0.02 \mu \mathrm{m}\right)$. The non-volatile fraction in the sub-micron aerosol and the aerosol absorption coefficient were measured as well. Trace gas data relevant for this study were $\mathrm{CO}$ and $\mathrm{H}_{2} \mathrm{O}$. Particularly $\mathrm{CO}$ is a very valuable tracer for smoke plumes emitted from fires. The terminus excess $\mathrm{CO}(\triangle \mathrm{CO})$ describes the $\mathrm{CO}$ above an average "unperturbed" profile. This enhanced CO above the "unperturbed" value is associated to fire plumes. The method for the determination of $\triangle \mathrm{CO}$ is described in the Appendix.

The use of volumetric units and aerosol modes throughout the paper requires explanation. If number or mass concentrations or aerosol absorption coefficients refer to standard temperature and pressure conditions STP $(273 \mathrm{~K}, 1013 \mathrm{hPa})$, they are given as particles per standard $\mathrm{cm}^{3}\left(\mathrm{scm}^{-3}\right), \mu \mathrm{g}$ per standard $\mathrm{m}^{3}\left(\mu \mathrm{g} \mathrm{sm}^{-3}\right)$, and absorption per standard $\mathrm{Mm}\left(\mathrm{sMm}^{-1}, 10^{-6} \mathrm{sm}^{-1}\right)$. These concentration data correspond to mixing ratios which do not depend on the respective pressure and temperature during the measurement. Otherwise concentration data refer to ambient conditions. The aerosol population is subdivided intro nucleation mode 
Table 1. Research flights performed during the ITOP core phase.

\begin{tabular}{cccccc}
\hline Mission ID & Date & UTC & FF smoke plumes & \multicolumn{2}{c}{ Location of FF encounters } \\
\hline 040719A & 19 July 2004 & $09: 23-10: 47$ & no & & \\
040722A & 22 July 2004 & $09: 40-10: 57$ & $4-9 \mathrm{~km}$ & $48.66^{\circ} \mathrm{N}$ & $0.37^{\circ} \mathrm{E}$ \\
& & & & $42.42^{\circ} \mathrm{N}$ & $9.83^{\circ} \mathrm{W}$ \\
040722B & 22 July 2004 & $15: 05-17: 03$ & $3-7 \mathrm{~km}$ & $42.93^{\circ} \mathrm{N}$ & $8.35^{\circ} \mathrm{W}$ \\
& & & & $43.48^{\circ} \mathrm{N}$ & $7.96^{\circ} \mathrm{W}$ \\
& & & $48.48^{\circ} \mathrm{N}$ & $2.73^{\circ} \mathrm{W}$ \\
040723A & 23 July 2004 & $12: 11-16: 02$ & $3-6 \mathrm{~km}$ & $48.70^{\circ} \mathrm{N}$ & $0.89^{\circ} \mathrm{E}$ \\
& & & & $48.39^{\circ} \mathrm{N}$ & $0.38^{\circ} \mathrm{E}$ \\
040725A & 25 July 2004 & $13: 37-16: 40$ & $3-5 \mathrm{~km}$ & $49.92^{\circ} \mathrm{N}$ & $2.12^{\circ} \mathrm{E}$ \\
040725B & 25 July 2004 & $17: 42-19: 53$ & $3-5 \mathrm{~km}$ & $49.36^{\circ} \mathrm{N}$ & $1.24^{\circ} \mathrm{E}$ \\
040726A & 26 July 2004 & $15: 07-18: 50$ & $3-4 \mathrm{~km}$ & $49.41^{\circ} \mathrm{N}$ & $5.06^{\circ} \mathrm{W}$ \\
040730A & 30 July 2004 & $15: 00-18: 35$ & $3-8 \mathrm{~km}$ & $49.00^{\circ} \mathrm{N}$ & $0.54^{\circ} \mathrm{E}$ \\
& & & & $49.33^{\circ} \mathrm{N}$ & $0.87^{\circ} \mathrm{E}$ \\
040731A & 31 July 2004 & 12:07-13:55 & no & & \\
\hline
\end{tabular}

Table 2. Instrumentation on board the research aircraft Falcon during ITOP 2004.

\begin{tabular}{|c|c|}
\hline Property & Instrumentation \\
\hline \multicolumn{2}{|l|}{ Aerosol properties } \\
\hline $\begin{array}{l}\text { Number concentration; } \\
\text { size distribution of ultrafine particles }\end{array}$ & $\begin{array}{l}\text { Condensation Particle Counters }(\mathrm{CPC}) \text { operated at } \\
\text { lower cut-off diameters } D_{\min }=0.004,0.015 \text {, and ap- } \\
\text { prox. } 0.08 \mu \mathrm{m}(\mathrm{CPC} \& \text { Diffusion Screen Separator DS })\end{array}$ \\
\hline \multicolumn{2}{|l|}{ Size distributions } \\
\hline Aitken mode & $\begin{array}{l}\text { Differential Mobility Analyzer (DMA): } \\
0.01<D<0.2 \mu \mathrm{m}\end{array}$ \\
\hline Dry state, accumulation mode & $\begin{array}{l}\text { Passive Cavity Aerosol Spectrometer Probe PCASP- } \\
\text { 100X: } 0.1 \mu \mathrm{m}<D<3.0 \mu \mathrm{m}\end{array}$ \\
\hline Ambient state, accumulation + coarse mode & $\begin{array}{l}\text { Forward Scattering Spectrometer Probe } \\
\text { FSSP 300: } 0.3 \mu \mathrm{m}<D<20 \mu \mathrm{m}\end{array}$ \\
\hline Volume fraction of volatile/refractory particles & $\begin{array}{l}\text { Thermodenuder }\left(T=20^{\circ} \mathrm{C} / 250^{\circ} \mathrm{C}\right) \text { connected to Con- } \\
\text { densation Particle Counters }(\mathrm{CPC}) \text { operated at lower } \\
\text { cut-off diameters } D_{\min }=0.004,0.015 \text {, and } 0.08 \mu \mathrm{m} \\
\text { (CPC \& Diffusion Screen Separator DS) }\end{array}$ \\
\hline \multicolumn{2}{|l|}{ Aerosol optical properties } \\
\hline $\begin{array}{l}\text { Volume absorption coeff., } \lambda=0.55 \mu \mathrm{m} \\
\text { Trace gases }\end{array}$ & Particle Soot Absorption Photometer PSAP \\
\hline $\mathrm{NO} / \mathrm{NO}_{\mathrm{y}}$ & Chemiluminescence detector \\
\hline $\mathrm{CO}$ & VUV fluorescence \\
\hline Ozone & UV absorption \\
\hline $\mathrm{CO}_{2}$ & IR absorption \\
\hline $\mathrm{H}_{2} \mathrm{O}$ & Tunable Diode Laser Spectrometer \\
\hline $\mathrm{SO}_{2}$ & Ion Trap Chemical Ionisation MS \\
\hline \multicolumn{2}{|l|}{ Atmospheric parameters } \\
\hline$T, p, \mathrm{RH}$ (BL, FT), 3D-wind velocity & Falcon standard instrumentation \\
\hline
\end{tabular}

particles NUC with $D_{p}<14 \mathrm{~nm}$, Aitken mode particles AITK with $14 \mathrm{~nm}<D_{p}<100 \mathrm{~nm}$, and accumulation mode particles ACC with $0.1 \mu \mathrm{m}<D_{p}<3.0 \mu \mathrm{m}$. Details of the data analysis procedure are given in the Appendix.

\subsection{The ITOP study - mountain observatories}

Long-term information on the aerosol loading over Central Europe in summer 2004 was obtained from two ground sites. At the GAW (Global Atmosphere Watch 
Program of WMO) observatories Jungfraujoch (http:// gaw.web.psi.ch/), operated by Paul Scherrer Institute PSI (CH) and Hohenpeissenberg (http://www.dwd.de/de/FundE/ Observator/MOHP/MOHP.htm), operated by the German Weather Service DWD, aerosol absorption is measured continuously by means of a Multi-Angle Absorption Photometer (MAAP) (Petzold and Schönlinner, 2004) which provides reliable absorption coefficient data (Sheridan et al., 2005; Petzold et al., 2005). The MAAP is operated on Jungfraujoch since March 2003 and on Hohenpeissenberg since spring 2004. The aerosol absorption coefficient $\sigma_{a p}$ at a wavelength $\lambda=550 \mathrm{~nm}$ can be converted to an equivalent $\mathrm{BC}$ mass concentration $\mathrm{BC}_{e}$ using a mass-specific absorption crosssection of $8 \mathrm{~m}^{2} \mathrm{~g}^{-1}$ (Bond and Bergstrom, 2006). The terminology equivalent $\mathrm{BC}$ follows a recommendation by Andreae and Gelencser (2006), since this BC value is derived from optical measurements and requires the assumption of a certain mass-specific absorption cross-section. As is discussed by Andreae and Gelencser (2006) and by Bond and Bergstrom (2006), the value for the mass-specific absorption cross-section may vary between 8 and $10 \mathrm{~m}^{2} \mathrm{~g}^{-1}$ for fresh and aged carbonaceous particles, respectively. $\mathrm{BC}_{e}$ values may be lowered by a factor of 1.25 if a mass-specific absorption cross-section of $10 \mathrm{~m}^{2} \mathrm{~g}^{-1}$ is used for an internally mixed and aged aerosol (Andreae and Gelencser, 2006; Bond and Bergstrom, 2006).

The high-alpine station Jungfraujoch is the scientific observatory at highest elevation ( $3580 \mathrm{~m}$ a.s.l.) within Europe, probing European background free tropospheric air in fall and winter while in summer air from the CBL can be lifted up to the Jungfraujoch observatory by means of convection (Baltensperger et al., 1997; Nyeki et al., 2000). Hohenpeissenberg at an elevation of $989 \mathrm{~m}$ a.s.l. is situated in the CBL almost all over the year. Within the GAW network it is defined as one Central European background site. The time series of $\sigma_{a p}$ and $\mathrm{BC}_{e}$ measured at the mountain observatories are used in the following (1) for estimating the free tropospheric background values for $\sigma_{a p}$ and $\mathrm{BC}_{e}$, and (2) for answering the question how far the North American forest fire smoke plumes penetrated into the European continental boundary layer.

\subsection{The Lagrangian Dispersion Model FLEXPART}

For investigating the smoke plume transport processes, we used both forward and backward simulations with the Lagrangian particle dispersion model FLEXPART (Stohl et al., 1998, 2005). As the model simulations have already been described in detail by Stohl et al. (2006), only a brief description is given here. FLEXPART releases so-called tracer particles at emission sources and calculates their trajectories using the mean winds interpolated from the meteorological input field plus random motions representing turbulence. Moist convective transport is considered. For the boreal forest fires, an emission inventory was constructed from daily
MODIS fire hot spot detection and daily fire reports. This inventory was then used to calculate a passive (no deposition processes, no chemistry) carbon monoxide (CO) tracer forward in time, which was converted into a $\mathrm{BC}$ tracer by using emission ratios between $\mathrm{CO}$ and $\mathrm{BC}$ taken from Andreae and Merlet (2001).

In addition, we ran FLEXPART backward in time (see Stohl et al., 2003, for a description) from a large number of short segments along the Falcon flight track. The resulting potential emission sensitivity function can be interpreted in a similar way as traditional back trajectory calculations but is based on a full dispersion model, including parameterised turbulent and convective transport. Together with the emission inventory, it can also be used to estimate the spatial distribution of emissions contributing to the measured $\mathrm{BC}$ along the flight track.

\subsection{The Aerosol-Climate Model ECHAM/MADE}

To gain information on the vertical distribution of $\mathrm{BC}$ over Central Europe for years with normal to low fire activities in North America an Siberia, we used the aerosolclimate model ECHAM/MADE. The coupled model system ECHAM/MADE consists of two main components, the general circulation model (GCM) ECHAM4 and the aerosol dynamics model MADE. Details on the model system and techniques used can be found in (Lauer et al., 2005) and the references therein. The ECHAM4 GCM (Röckner et al., 1996) is a spectral model. The horizontal resolution applied in this study is T30, which corresponds to a Gaussian grid of about $3.75^{\circ} \times 3.75^{\circ}$ (longitude by latitude). The atmosphere is divided into 19 vertical layers from the surface up to $10 \mathrm{hPa}(\sim 30 \mathrm{~km})$ using a hybrid $\sigma-p$ coordinate system. ECHAM4 uses a semi-Lagrangian advection scheme (Rasch et al., 1990). The ECHAM version applied in this study includes two major upgrades compared to the standard version of the GCM: extended cloud microphysics (Lohmann et al., 1999) and an aerosol module describing the mass concentrations of several aerosol species (Feichter et al., 1996). This aerosol module is used to drive the cloud and the radiation scheme of the GCM.

Aerosol dynamics are represented by the submodule MADE (Ackermann et al., 1998) which describes the aerosol size-distribution by the sum of three log-normally distributed modes, the Aitken (typically smaller than $0.07 \mu \mathrm{m}$ ), accumulation (about $0.07-1 \mu \mathrm{m}$ ) and coarse mode (particles larger than $1 \mu \mathrm{m}$ ). All particles are assumed to be internally mixed. Aerosol components considered are $\mathrm{SO}_{4}, \mathrm{NH}_{4}, \mathrm{NO}_{3}, \mathrm{BC}$, organic matter $(\mathrm{OM})$, sea salt, mineral dust, and aerosol liquid water in the two sub-micron modes. The coarse mode consists of mineral dust, sea salt, and aerosol liquid water. In addition to the mass concentration of the individual aerosol components, particle number concentration and the median particle diameter of each mode are calculated explicitly, taking into account coagulation, nucleation and con- 
(a) Column-integrated potential emission sensitivity

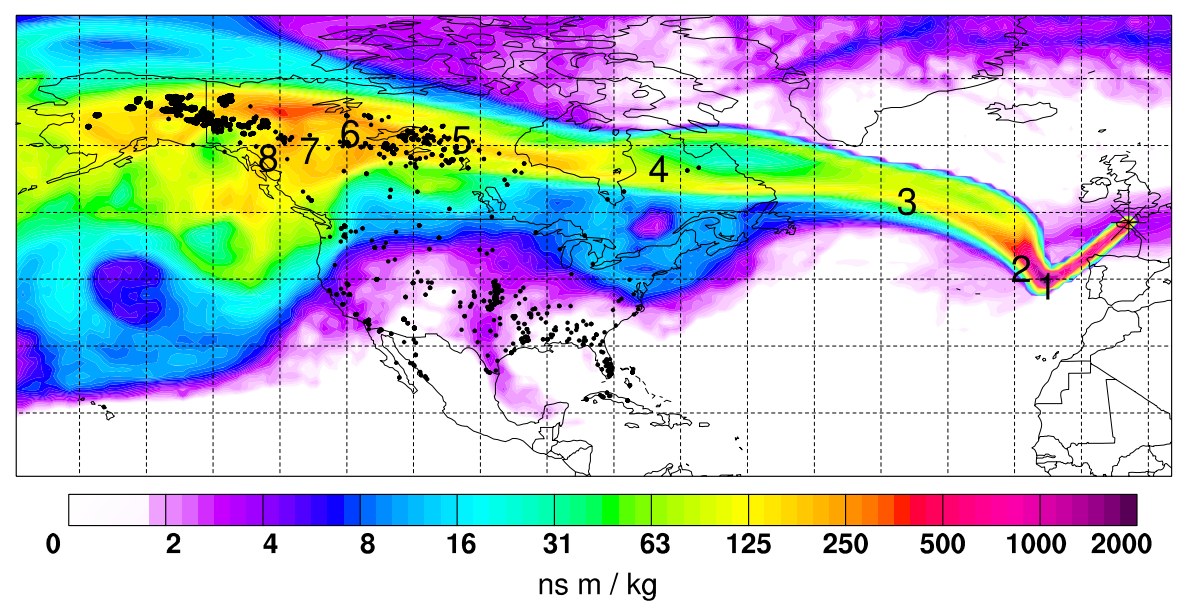

Maximum value $0.211 \mathrm{E}+04 \mathrm{~ns} \mathrm{~m} / \mathrm{kg}$

(b) footprint potential emission sensitivity

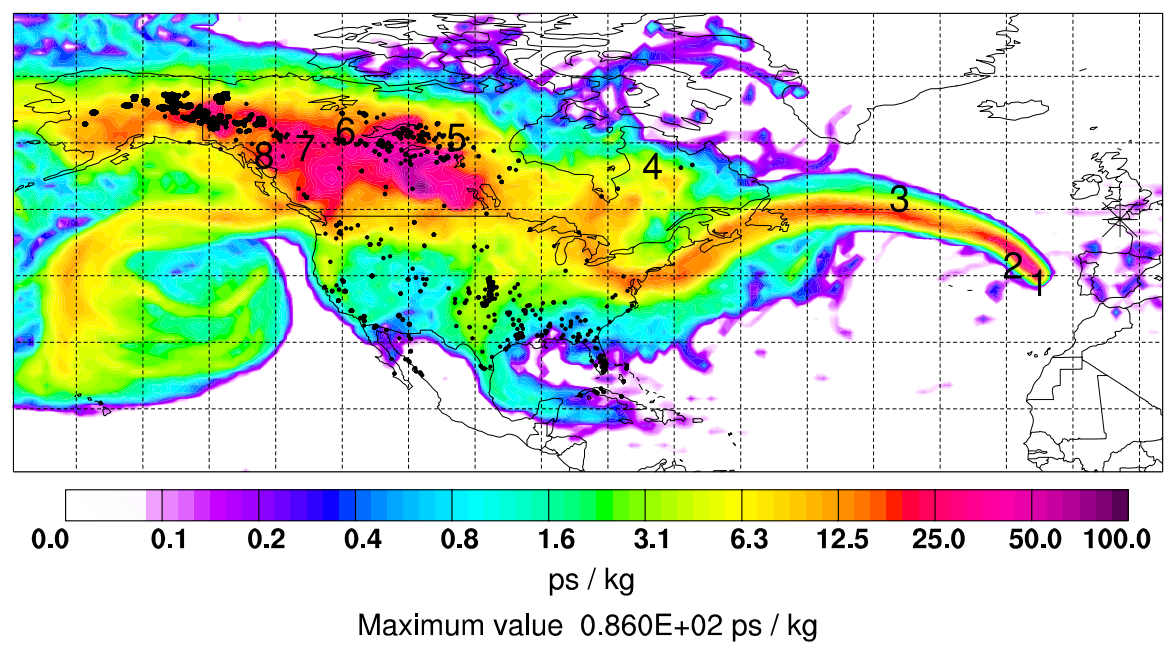

Fig. 2. Retroplume results from the backward simulation for flight 040722B from 16:22:02 to 16:23:18 UTC. Shown are (a) the columnintegrated PES and (b) the footprint PES. Dots identify fire hot spots detected by MODIS, numbers along the plume refer to transport times in days since emission.

densation of sulphuric acid vapour, size-dependent wet and dry deposition, emission of primary particles, aerosol chemistry, gas/aerosol partitioning, and cloud processing. In the MADE version applied here, the geometric standard deviation (GSD) of the modal size distributions is kept constant using GSD=1.7 for the Aitken mode, GSD=2.0 for the accumulation mode, and GSD=2.2 for the coarse mode.

Recent analyses of total carbon emissions from boreal wildland fires showed that year 2000 emissions were $22 \%$ below average emissions for the period 1992-2003 (Kasischke et al., 2005; van der Werf et al., 2006). Referring to the period from 1997 to 2004, emissions from large-scale wild- land burning in boreal areas were highest in 1998 and 2004, and lowest in 2000 and 2001 (van der Werf et al., 2006). Year 2000 can therefore considered a reference year with normal to low boreal fire emissions. The ECHAM/MADE runs used year 2000 emissions for biomass burning (BC, particulate organic matter $\mathrm{POM}, \mathrm{SO}_{2}$ ) and follow the AeroCom recommendations (Dentener et al., 2006). This emission data set includes large-scale wildfire emissions which are based on the studies of van der Werf et al. (2004) on the continentalscale partitioning of wildfire emissions for the period from 1997 to 2001. 


\section{Results}

3.1 The smoke plume from 22-23 July 2004

During two flights on 22 July from Creil (France) to Santiago (Spain) and back and on July 23 from Creil to the English Channel and back, an aerosol plume emitted from strong boreal forest fires in Alaska was probed at altitudes between 3 and $6 \mathrm{~km}$ a.s.l., see also Fig. 1. FLEXPART backward analyses are used to estimate the contribution of smoke aerosols to the observed plume. The results suggest a dominant fraction of forest fire aerosol in the sample. For a short sequence of the encountered smoke plume, its source region is shown in Fig. 2 in terms of a column-integrated potential emission sensitivity from a FLEXPART backward simulation for the analysed Falcon flight track with superimposed MODIS fire hot spot locations. The value of the potential emission sensitivity function (PES; Stohl et al., 2003) in a particular grid cell in units of $\mathrm{sg}^{-1}$ is proportional to the plume residence time in that cell. It is a measure for the simulated mixing ratio at the receptor that a source of unit strength in the respective grid cell would produce. The footprint PES corresponds to a layer extending from $0-100 \mathrm{~m}$ above ground. The PES integrated over the entire atmospheric column (Fig. 2a) illustrates the pathway of the polluted air mass. The footprint PES plot (Fig. 2b) suggests that the vast majority of emissions contributing to the plume probed by the Falcon on 22 July were released from fires in Alaska and Northwest Canada about 5-8 days prior to measurement. Upstream the fire regions no significant contributing source is found. The source region does not differ significantly, if other sequences of the plume encounter are analysed.

Figure 3 gives an overview map of the plume event of 22 July based on a FLEXPART forward simulation. We used a constant ratio of $\mathrm{BC} / \Delta \mathrm{CO}=5.2 \mathrm{mg} \mathrm{BC}(\mathrm{g} \Delta \mathrm{CO})^{-1}$ for boreal fire emission conditions (Andreae and Merlet, 2001) in order to illustrate the $\mathrm{BC}$ columnar loads across the smoke plume event. All biomass burning emissions over North America were taken into account for this simulation, and particles were carried in the model for 30 days. It can be taken from Fig. 3, that the Falcon plume encounters at the northern did not probe the core of the plume.

Forward trajectories and $\mathrm{BC}$ monitoring data from the mountain sites indicate that a part of this plume crossed the high-alpine research station Jungfraujoch about $36 \mathrm{~h}$ after being probed by the Falcon. In contrast, no plume signatures were observed in the $\mathrm{BC}$ record of the CBL background observatory Hohenpeissenberg. It can be concluded that north of the Alps the plume was transported in the free troposphere over Central Europe without significant downward mixing.

Figure 4 demonstrates two examples of the complex structure of vertical aerosol profiles encountered during these long-range transport events. Plume ages inferred from FLEXPART are 7-9 days for the plume at 22 July and 4-6 days for the plume at 30 July. The profiles contain $\Delta \mathrm{CO}$,

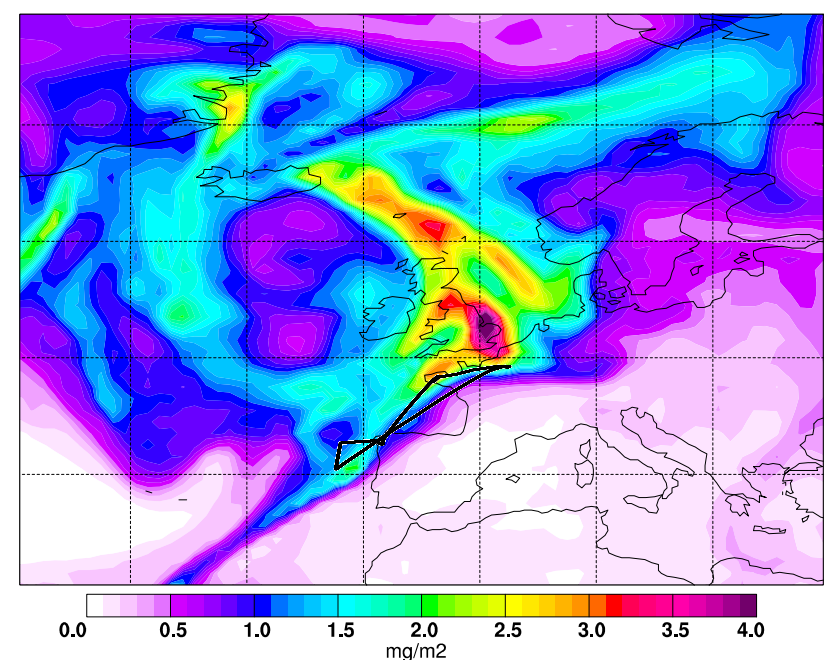

Fig. 3. Integral BC columnar load calculated from FLEXPART analyses for 22 July 2004, 12:00 UTC; the Falcon flight tracks for flights 040722A and 040722B are shown by the black solid lines.

PM 2.5 mass concentration and aerosol size distributions from combined DMA and PCASP data. In both cases, the polluted CBL reaches up to an altitude of $2.0 \mathrm{~km}$ and is dominated by high PM 2.5 mass concentrations and high number densities in the NUC mode. From $4.0 \mathrm{~km}$ to approx. $8.0 \mathrm{~km}$ altitude, a clearly layered structure is observed which can be attributed to forest fire smoke plumes. All polluted layers in the FT are characterised by PM 2.5 values of similar magnitude as in the CBL. Size distributions of the forest fire aerosol are dominated by a strong ACC mode while the NUC mode is almost entirely depleted. Such an absence of the NUC mode is here identified as one of the key properties characterising the aerosol in boreal forest fire plumes after 1-2 weeks of atmospheric transport. Details of the size distribution will be discussed later.

\subsection{2 The European free troposphere for periods of nor-} mal fire activity

An assessment of the perturbation of the FT aerosol above Europe by North American forest fire smoke plumes requires comparison data for a FT aerosol for periods without strong forest fire activities in the northern hemisphere. The expected range of $\mathrm{BC}$ mass concentrations in the free and upper free troposphere is $<1-10 \mathrm{ng} \mathrm{m}^{-3}$ (Hendricks et al., 2004). The PSAP with its detection limit of approx. $0.1 \mathrm{sMm}^{-1}$ is not capable of measuring such low $\mathrm{BC}_{e}$ levels with a time resolution required for airborne studies. The recently introduced SP-2 instrument (Baumgardner et al., 2004) based on the technique of laser-induced incandescence may be applicable to this type of measurement. First intercomparison studies in the laboratory (Slowik et al., 2006) and airborne measurements (Schwarz et al., 2006) yield promising results. 

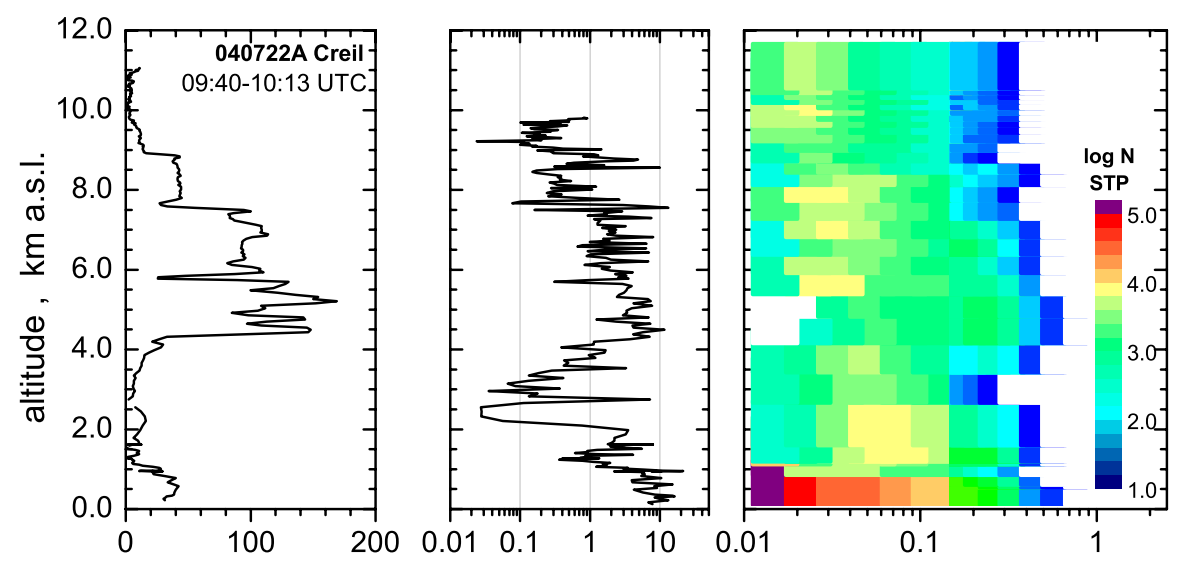

$\Delta \mathrm{CO}, \mathrm{nmol} \mathrm{mol}^{-1} \quad \mathrm{PM} 2.5, \mu \mathrm{g} \mathrm{sm}^{-3}$
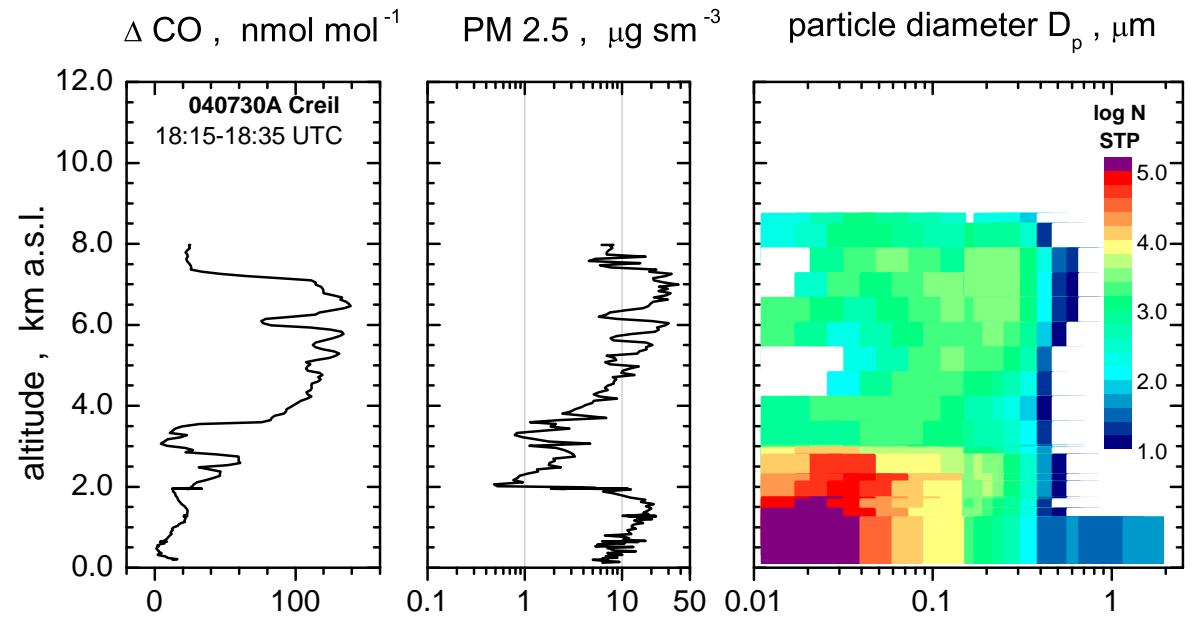

$\Delta \mathrm{CO}, \mathrm{nmol} \mathrm{mol}^{-1}$

$\mathrm{PM} 2.5, \mu \mathrm{g} \mathrm{sm}^{-3}$

particle diameter $D_{p}, \mu m$

Fig. 4. Profiles of excess CO (left), particulate matter mass concentration for standard conditions PM 2.5 (mid), and particle size distribution for standard conditions (right) for Creil on 22 July (ascent) and on 30 July (descent).

However, the instrument is not yet widely in use. The vertical profile of the aerosol absorption coefficient and the $\mathrm{BC}$ mass concentration for periods without strong fire activities have thus to be estimated by a different approach.

During various field studies conducted by DLR Institute of Atmospheric Physics in Central Europe in the years 2000 to 2002 (Minikin et al., 2003), the vertical distribution of nonvolatile particles was measured for summer (UFA/EXPORT data) and late fall to winter (SCAVEX data) conditions. The field experiment UFA/EXPORT was conducted in July and August 2000 over Central Europe with flights from Switzerland to Czech Republic and from Northern Italy to Northern Germany. Flights during the SCAVEX experiment took place from Oberpfaffenhofen in November 2002 in the vicinity of the Alps. Both experiments extended over three weeks and provided data from 20-25 flights hours. The vertical profiles of aerosol number concentrations were calculated by statistical methods as median, 10-percentile and 90-percentile val- ues for cloud-free flight sequences. No further separations according to meteorological conditions were made.

The presented extrapolation approach for a vertical profile of BC mass concentration at "clean" conditions with normal fire activities makes use of the fact that $\mathrm{BC}$ is part of the non-volatile aerosol fraction of the atmospheric aerosol. The only necessary key assumption for the FT and the UT/LS is that the $\mathrm{BC}$ mass concentrations vary with altitude similar to the number concentration of non-volatile particles, i.e., $\mathrm{BC}_{e} / \mathrm{N}_{\text {nonvol }}=$ constant. This key assumption is reasonable for the well-aged free tropospheric aerosol. It does of course not hold for the CBL where continuous input of non-volatile particles from surface sources is active. The FT background concentration of $\mathrm{BC}_{e}$ can be extracted from long-term records of $\mathrm{BC}_{e}$ at the Jungfraujoch observatory which is situated in the European FT during winter. Late fall to winter vertical profiles of $\mathrm{N}_{\text {nonvol }}$ from SCAVEX are combined with Jungfraujoch winter time data to get an esti- 
mate for $\mathrm{BC}_{e} / \mathrm{N}_{\text {nonvol }}$. The vertical profiles of $\mathrm{N}_{\text {nonvol }}$ from UFA/EXPORT representing Central European summer conditions are then combined with the constant ratio $\mathrm{BC}_{e} / \mathrm{N}_{\text {nonvol }}$ for the extrapolation of the $\mathrm{BC}$ mass concentration profile over Europe for summer conditions.

Analysing three winter time series (winter seasons 2003/2004, 2004/2005, and 2005/2006) of Jungfraujoch data, a minimum $24 \mathrm{~h}$ average $\mathrm{BC}$ mass concentration of $2.7 \mathrm{ng} \mathrm{m}^{-3}$ and a 10-percentile value of $6.0 \mathrm{ng} \mathrm{m}^{-3}$ are obtained. From airborne data for late fall to winter conditions the median $\mathrm{N}_{\text {nonvol }}$ value at the same altitude as the Jungfraujoch observatory elevation of $3580 \mathrm{~m}$ a.s.l. is $110 \mathrm{~cm}^{-3}$ with 10-percentile and 90-percentile values of $60 \mathrm{~cm}^{-3}$ and $235 \mathrm{~cm}^{-3}$. Table 3 summarises median number concentrations for the relevant altitude ranges of FT $(5-7 \mathrm{~km})$ and UT/LS $(9-11 \mathrm{~km})$ and the statistical analysis of the data used from field experiments and from the Jungfraujoch observatory.

For the determination of the $\mathrm{FT}$ value for $\mathrm{BC}_{e} / \mathrm{N}_{\text {nonvol }}$ the 10-percentile value of the $\mathrm{BC}$ concentration at Jungfraujoch is assumed to be more robust than the minimum mass concentration which may represent a unique event. Combining the 10-percentile value for $\mathrm{BC}_{e}$ of $6.0 \mathrm{ng} \mathrm{m}^{-3}$ with a median value for $\mathrm{N}_{\text {nonvol }}$ of $110 \mathrm{~cm}^{-3}$ at the Jungfraujoch elevation results in $\mathrm{BC}_{e} / \mathrm{N}_{\text {nonvol }}=5.5 \times 10^{-17} \mathrm{~g}$ BC per nonvolatile particle. Using the minimum $\mathrm{BC}_{e}$ value, a ratio $\mathrm{BC}_{e} / \mathrm{N}_{\text {nonvol }}=2.5 \times 10^{-17} \mathrm{~g} \mathrm{BC}$ per non-volatile particle is obtained. These two ratios are used for the conversion of measured vertical profiles of $\mathrm{N}_{\text {nonvol }}$ into profiles of $\mathrm{BC}_{e}$. The $\mathrm{BC}$ mass concentrations obtained by this approach are also compiled in Table 3 for Central European summer and winter conditions. The detailed profile data are summarised in Table 4 and plotted in Fig. 5.

Estimated BC mass concentrations span over a range of 3-6 ng $\mathrm{m}^{-3}$ at FT (5-7 kma.s.1.) and $1-4 \mathrm{ng} \mathrm{m}^{-3}$ at UT (9-11 kma.s.1.) altitude. The obtained $\mathrm{BC}_{e}$ values are in reasonable agreement with values estimated from SP-2 observations (Schwarz et al., 2006) and with results from recent model studies (Hendricks et al., 2004). Hendricks et al. (2004) report a range of $0.1-10 \mathrm{ng} \mathrm{m}^{-3}$ for BC mass concentrations in the global UTLS region and $>1 \mathrm{ng} \mathrm{m}^{-3}$ at northern midlatitudes, while Schwarz et al. (2006) measured $\leq 2 \mathrm{ng} \mathrm{m}^{-3}$ at approx. $6 \mathrm{~km}$ a.s.l. and $<1 \mathrm{ng} \mathrm{m}^{-3}$ at $10 \mathrm{~km}$ a.s.l. over Texas in November 2004.

As a final step, the $\mathrm{BC}$ mass concentration profile obtained from ECHAM/MADE for July/August 2000 over Central Europe (model grid section: $5.6^{\circ} \mathrm{E}-13.1^{\circ} \mathrm{E}, 44.5^{\circ} \mathrm{N}-$ $52.0^{\circ} \mathrm{N}$ ) is compared to the profile estimated from FT field data over Central Europe in July/August 2000. The result is shown in Fig. 5. The data from the extrapolation approach are shown as intervals per altitude. The bounding values are calculated from the minimum $\mathrm{BC}_{e}$ (lower bound) and the 10percentile $\mathrm{BC}_{e}$ (upper bound) values for the determination of the $\mathrm{BC}$ mass per non-volatile particle. Both $\mathrm{BC}$ profiles agree reasonably well at FT and UT altitudes. This gives rise to

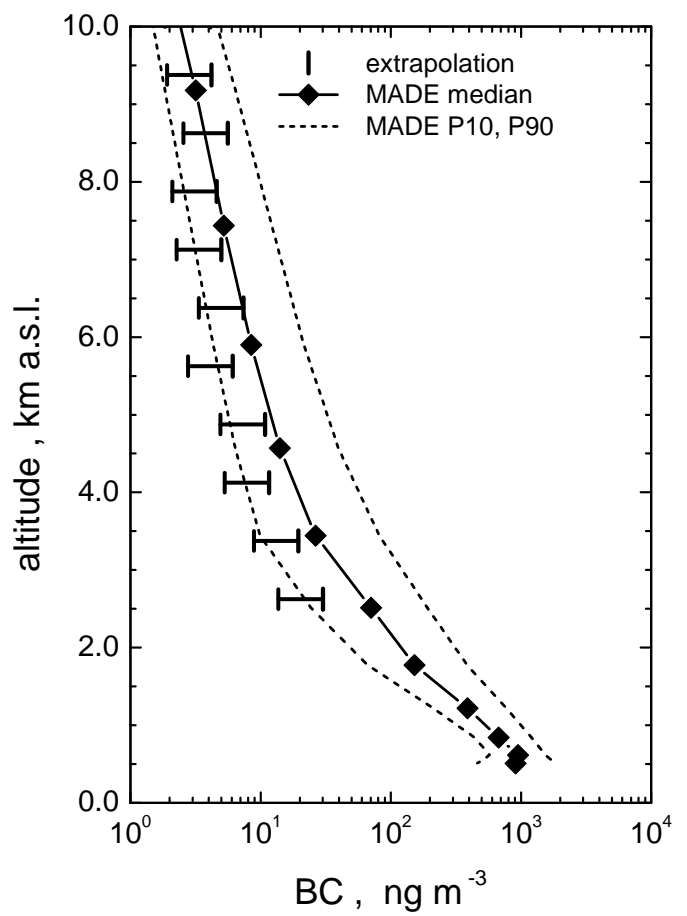

Fig. 5. Vertical profiles of the black carbon mass concentration (BC) for unperturbed Central European summer conditions: lines and symbols refer to 10-percentile, 90-percentile, and median values from ECHAM/MADE for Central Europe in July/August 2000, horizontal bars indicate the $\mathrm{BC}$ mass concentration extrapolated from Jungfraujoch data and vertical profiles of non-volatile particles over Central Europe in July/August 2000.

the assumption that the vertical distribution of $\mathrm{BC}_{e}$ as shown in Fig. 5 is a valuable reference case for the assessment of the FT perturbations caused by the summer 2004 forest fire smoke plumes.

3.3 The vertical distribution of aerosols and trace gases during ITOP

The vertical distribution of aerosol modes and $\mathrm{CO}$ during ITOP in summer 2004 is plotted in Fig. 6. In Fig. 6a all cloud-free aerosol data measured during ITOP are shown as $5 \mathrm{~s}$ averages. CO data are given with $1 \mathrm{~s}$ time resolution. Brown symbols represent flights with forest fire smoke plume encounters while blue symbols refer to those flights without smoke plume encounters. In-cloud sequences are excluded since liquid water clouds may disturb the measurement of particle number concentrations. The white solid lines represent the median number concentrations for conditions without fire smoke plumes. The statistical analysis of the same data set is plotted in Fig. $6 \mathrm{~b}$ as median, 10percentile and 90-percentile vertical profiles. In contrast to Fig. 6a, the $\mathrm{CO}$ volume mixing ratio is represented as $\Delta \mathrm{CO}$. Median number concentration profiles for conditions without fire smoke plumes are added as broken lines. 
Table 3. Number concentration $(\mathrm{N})$ of non-volatile particles in the upper free troposphere (UT) of the northern hemisphere (NH) and at the level of the Jungfraujoch (JFJ) observatory, derived from vertical aerosol profiles, equivalent black carbon mass concentrations $\mathrm{BC}_{e}$ at $\mathrm{JFJ}$ and extrapolated to UT concentration levels; P10 and P90 refer to 10-percentile and 90-percentile values.

\begin{tabular}{|c|c|c|}
\hline & $\begin{array}{l}\text { Summer } \\
\text { June-Aug }\end{array}$ & $\begin{array}{l}\text { Winter } \\
\text { Dec-Feb }\end{array}$ \\
\hline \multicolumn{3}{|l|}{$\begin{array}{l}\text { Jungfraujoch, } 3.5 \mathrm{~km} \text { a.s.l. } \\
24 \mathrm{~h} \text { average } \mathrm{BC}_{e}, \mathrm{ng} \mathrm{m}^{-3}\end{array}$} \\
\hline Maximum & 500 & 370 \\
\hline P90 & 278 & 89 \\
\hline Median & 114 & 18.5 \\
\hline P10 & 32.6 & 6.0 \\
\hline Minimum & 5.9 & 2.7 \\
\hline \multicolumn{3}{|l|}{ European FT/UT $\left.{ }^{1}\right)$} \\
\hline \multicolumn{3}{|l|}{ JFJ altitude, $3.5 \mathrm{~km}$} \\
\hline $\mathrm{N}_{\text {nonvol }}, \mathrm{cm}^{-3}$, median $(\mathrm{P} 10, \mathrm{P} 90)$ & $350(170-870)$ & $110(60-235)$ \\
\hline $\mathrm{BC}_{e}, \mathrm{ng} \mathrm{m}^{-3}$, median $(\mathrm{P} 10, \mathrm{P} 90)$ & $19.2(9.4-47.9)$ & $6.0(3.3-12.9)$ \\
\hline \multicolumn{3}{|l|}{ Free Troposphere, 5-7 km } \\
\hline $\mathrm{N}_{\text {nonvol }}, \mathrm{cm}^{-3}$ & $80-140$ & $60-100$ \\
\hline $\mathrm{BC}_{e}, \mathrm{ng} \mathrm{m}^{-3}$ & $4.4-6.1^{2)}$ & $3.3-5.5^{2)}$ \\
\hline \multicolumn{3}{|l|}{ Upper Troposphere, 9-11 km } \\
\hline $\mathrm{N}_{\text {nonvol }}, \mathrm{cm}^{-3}$ & $50-80$ & $25-40$ \\
\hline $\mathrm{BC}_{e}, \mathrm{ng} \mathrm{m}^{-3}$ & $2.8-4.4^{2)}$ & $1.4-2.2^{2)}$ \\
\hline
\end{tabular}

1) Summer data originate from the study UFA/EXPORT in July and August 2000, winter data originate from the study SCAVEX in November 2002 (Minikin et al., 2003).

2) Extrapolation uses a ratio of $\mathrm{BC}_{e} / \mathrm{N}_{\text {nonvol }}=5.5 \times 10^{-17} \mathrm{~g}$ particle $^{-1}$, based on $\mathrm{N}_{\text {nonvol }}(\mathrm{JFJ}$ winter $)=110 \mathrm{~cm}^{-3} \mathrm{and} \mathrm{BC}_{e}(\mathrm{P} 10)=6.0 \mathrm{ng} \mathrm{m}^{-3}$ of JFJ data.

Table 4. Vertical profile data for the free troposphere (FT) number concentration of non-volatile particles $\mathrm{N}_{\text {nonvol }}$ and equivalent BC mass concentration $\mathrm{BC}_{e}$, derived from field data; reported data are median, 10-percentile (P10) and 90-percentile (P90) values of the analysed data set; altitude bands are averaged over $750 \mathrm{~m}$ thickness.

\begin{tabular}{|c|c|c|c|c|c|c|c|c|}
\hline \multirow[b]{2}{*}{$\begin{array}{l}\text { altitude } \\
\text { km a.s.l. }\end{array}$} & \multicolumn{3}{|c|}{$\begin{array}{c}\mathrm{N}_{\text {nonvol }} \\
\text { continental winter } 2002\end{array}$} & \multicolumn{3}{|c|}{$\begin{array}{c}\mathrm{N}_{\text {nonvol }} \\
\text { continental summer } 2000\end{array}$} & \multicolumn{2}{|c|}{$\begin{array}{c}\mathrm{BC}_{e} \\
\text { continental summer } 2000\end{array}$} \\
\hline & $\begin{array}{c}\text { median } \\
\mathrm{cm}^{-3}\end{array}$ & $\begin{array}{c}\mathrm{P} 10 \\
\mathrm{~cm}^{-3}\end{array}$ & $\begin{array}{c}\mathrm{P} 90 \\
\mathrm{~cm}^{-3}\end{array}$ & $\begin{array}{c}\text { median } \\
\mathrm{cm}^{-3}\end{array}$ & $\begin{array}{c}\mathrm{P} 10 \\
\mathrm{~cm}^{-3}\end{array}$ & $\begin{array}{c}\mathrm{P} 90 \\
\mathrm{~cm}^{-3}\end{array}$ & $\begin{array}{l}\operatorname{median}^{1)} \\
\mathrm{ng} \mathrm{m}^{-3}\end{array}$ & $\begin{array}{l}\operatorname{median}^{2)} \\
\mathrm{ng} \mathrm{m}^{-3}\end{array}$ \\
\hline 2625 & 320 & 105 & 395 & 550 & 280 & 1420 & 30.2 & 13.7 \\
\hline 3375 & 110 & 60 & 235 & 355 & 170 & 870 & 19.5 & 8.8 \\
\hline 4125 & 110 & 55 & 565 & 210 & 75 & 485 & 11.6 & 5.3 \\
\hline 4875 & 100 & 60 & 220 & 195 & 80 & 600 & 10.8 & 4.9 \\
\hline 5625 & 100 & 30 & 285 & 110 & 65 & 195 & 6.1 & 2.8 \\
\hline 6375 & 75 & 40 & 115 & 135 & 40 & 270 & 7.4 & 3.4 \\
\hline 7125 & 75 & 35 & 110 & 90 & 30 & 275 & 5 & 2.3 \\
\hline 7875 & 60 & 25 & 100 & 85 & 40 & 260 & 4.6 & 2.1 \\
\hline 8625 & 45 & 10 & 55 & 100 & 55 & 215 & 5.6 & 2.5 \\
\hline 9375 & 45 & 35 & 60 & 75 & 45 & 195 & 4.2 & 1.9 \\
\hline 10125 & 40 & 30 & 65 & 75 & 35 & 125 & 4.1 & 1.9 \\
\hline 10875 & 35 & 30 & 45 & 50 & 15 & 125 & 2.9 & 1.3 \\
\hline 11625 & 25 & 20 & 30 & 15 & 10 & 50 & 0.8 & 0.4 \\
\hline
\end{tabular}

1) $\mathrm{BC}_{e} / \mathrm{N}_{\text {nonvol }}=5.5 \times 10^{-17} \mathrm{~g} \mathrm{BC}$ per non-volatile particle.

2) $\mathrm{BC}_{e} / \mathrm{N}_{\text {nonvol }}=2.5 \times 10^{-17} \mathrm{~g} \mathrm{BC}$ per non-volatile particle. 

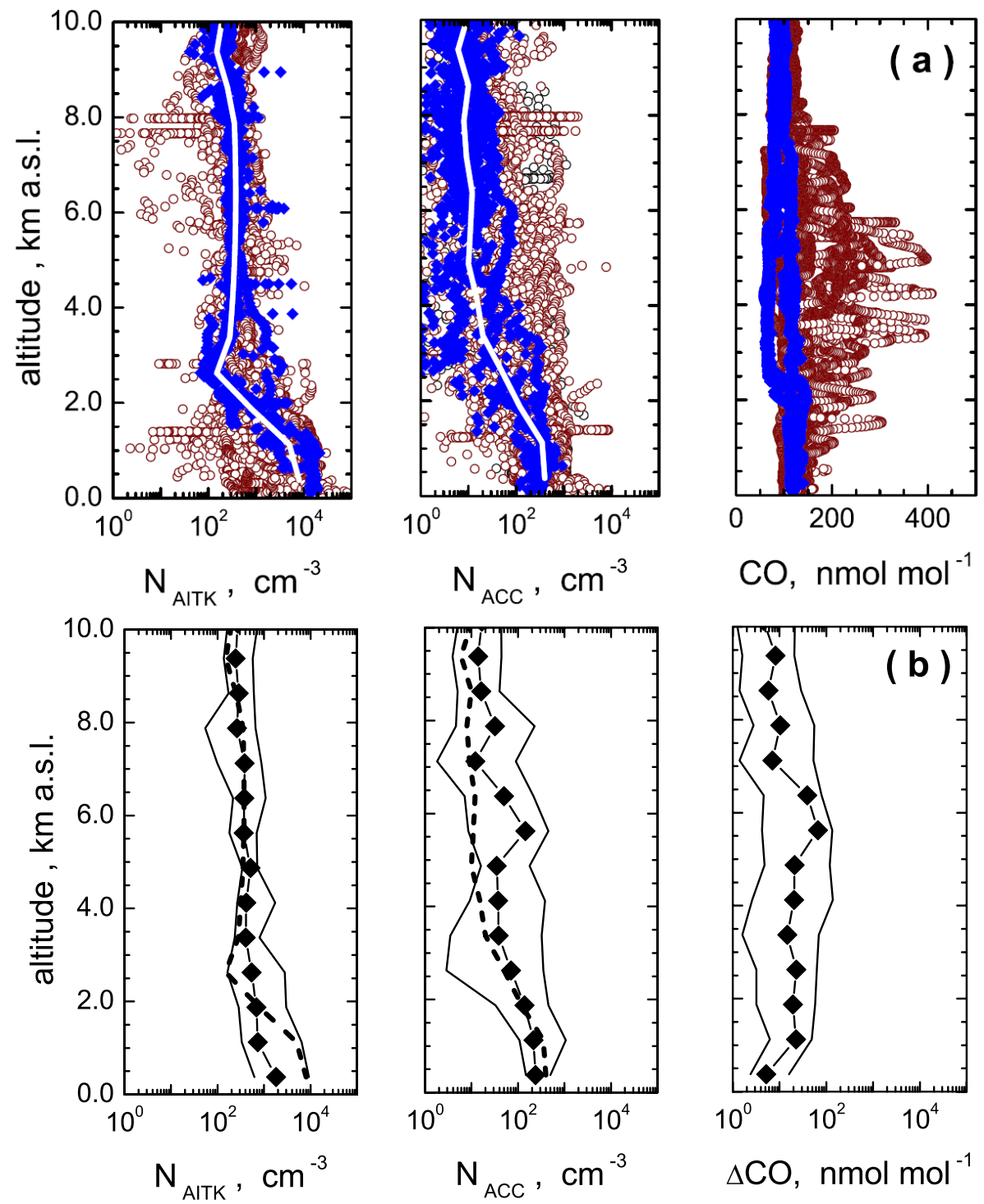

Fig. 6. Vertical profiles of aerosol number concentrations and CO mixing ratios measured during ITOP: (a) Number concentrations of Aitken (AITK), and accumulation (ACC) modes, and CO; flights with (without) smoke plume encounters are shown in brown (blue). (b) Median number concentrations of AITK and ACC modes, and excess $\mathrm{CO}(\triangle \mathrm{CO})$; symbols represent median values, solid lines correspond to P10 and P90 values. White lines in (a) and dotted lines in (b) refer to the median profiles of AITK and ACC for flights without smoke plume encounters.

Significant differences between smoke plume profiles and non-smoke plume profiles occur in the altitude band between 3.0 and $8.0 \mathrm{~km}$ a.s.l. for $\triangle \mathrm{CO}$, and for the ACC mode. For the ACC mode, the "unperturbed" median values is close to the 10-percentile value of the profiles influenced by smoke plumes, i.e., the deviation is statistically significant. In the case of $\Delta \mathrm{CO}$, the deviation is not that strong, but the "unperturbed" median value is still smaller than the 25 -percentile value of the profiles influenced by smoke plumes. For the AITK mode no significant difference is found.
Thus, forest fire smoke plumes seem to have only a minor impact on the AITK mode aerosol of the FT. For the ACC mode aerosol and $\triangle \mathrm{CO}$ the situation is different. A statistically significant enhancement of number concentrations compared to the data for non-smoke plume conditions is found for the altitude range of 5-6 km a.s.l. where the median values for non-smoke plume conditions are close to P10 values of smoke plume conditions. The increase in median ACC mode number concentrations is of the order of one magnitude (factor 5-15). An almost similar distribution with altitude is found for $\triangle \mathrm{CO}$ where the largest values also occur at 5-6 $\mathrm{km}$ a.s.l. 

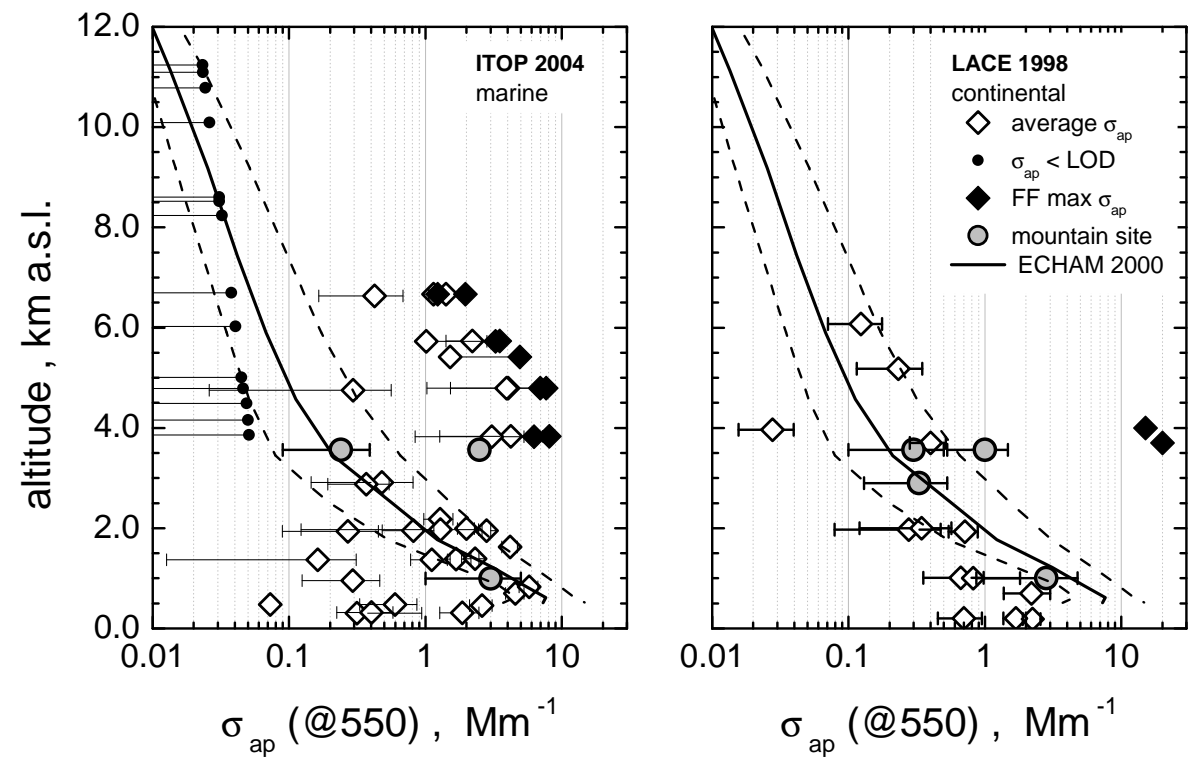

Fig. 7. Vertical profile of the aerosol absorption coefficient $\sigma_{a p}$ at $\lambda=550 \mathrm{~nm}$ from constant-altitude averaged airborne data (open symbols), forest fire smoke plume maximum airborne data (filled symbols), and data from mountain sites (circles): Jungfraujoch (3580 m a.s.1, average winter; average summer), Zugspitze (2980 m a.s.1., summer 2000), Kleiner Feldberg ( $825 \mathrm{~m}$ a.s.1., fall 2000) and Hohenpeissenberg (998 m a.s.1., summer 2004). Filled symbols with drop lines identify levels where the PSAP was below its detection limit of $0.1 \mathrm{sMm}^{-1}$. Data of the left panel refer to year 2004 ITOP measurements, data of the right panel refer to years 1998 (LACE 98) and 2000 (mountain sites). Solid and dashed lines refer to median and 10-percentile as well as 90-percentile values from ECHAM/MADE for continental Europe in July/August 2000 which were converted to $\sigma_{a p}$ values using a mass-specific absorption cross section of $8 \mathrm{~m}^{2} \mathrm{~g}^{-1}$.

By far the largest perturbation of the FT aerosol is observed for the aerosol absorption coefficient $\sigma_{a p}$. As is discussed in detail in the data analysis section, the PSAP absorption coefficient data were interpreted only for constantaltitude flight sequences which sum up to more than 50 constant altitude levels during ITOP. The left panel of Fig. 7 summarises all $\sigma_{a p}$ data inferred from PSAP measurements. Small symbols with drop lines correspond to levels with $\sigma_{a p}$ being below the detection limit of the PSAP. We set $\sigma_{a p, \min }=0.1 \mathrm{sMm}^{-1}$ (see Appendix). The conversion of standard to ambient conditions used measured pressure and temperature data. The error bars for levels with $\sigma_{a p}>\sigma_{a p \text {, min }}$ represent one standard deviation of the variability of $\sigma_{a p}$ for the analysed flight leg. Full symbols refer to 95-percentile values for the respective flight legs. The $\sigma_{a p}$ values measured at Jungfraujoch observatory during the forest fire plume encounter and averaged over the period of May-July 2004 are added to Fig. 7. The values fit well into the picture of airborne observations.

In the altitude range from 4 to $7 \mathrm{~km}$, the forest fire smoke plumes enhance $\sigma_{a p}$ by a factor of 100 compared to year 2000 conditions simulated by ECHAM/MADE. Again, a mass specific absorption cross-section of $8 \mathrm{~m}^{2} \mathrm{~g}^{-1}$ was used for the conversion of $\mathrm{BC}$ mass concentration to aerosol absorption. Inside the smoke plumes $\sigma_{a p}$ reaches maximum values of similar magnitude as have been measured in the urban pollution outflow from the greater Paris area during the ITOP observation phase. The polluted CBL values are also shown in the left panel of Fig. 7. On the other hand, polluted CBL values of $\sigma_{a p}$ are in good agreement with the values calculated from ECHAM/MADE so that the model source terms for local pollution seem to match the observations. As expected data measured in the clean MBL deviate significantly from the ECAHM/MADE results for Central Europe towards smaller values. The data collected during the LACE 98 experiment (Petzold et al., 2002) south-east of Berlin, Germany, and from several mountain sites as Jungfraujoch, Zugspitze and Hohenpeissenberg support the ECHAM/MADE: on the right panel of Fig. 7, FT data agree with the background vertical distribution from ECHAM/MADE, while the forest fire smoke plume observed during LACE 98 is of similar intensity as the plumes encountered during ITOP in summer 2004. This in turn means that such strong forest fire smoke plume events as observed in 2004 are not that uncommon.

\subsection{Forest fire aerosol properties}

Table 5 compiles a sub-set of the analysed constant-altitude sequences which contains all flight sequences with forest fire smoke encounters, all free-tropospheric flight legs at clean and almost unperturbed conditions and a representative set of flight legs inside the polluted CBL near Creil. Forest fire smoke plumes were also encountered during ascent or 
Table 5. Properties of probed atmospheric layers inferred from constant-altitude flight sequences ${ }^{1)}$ for forest fire smoke plumes (FF), clean or almost unpolluted free troposphere (FT) and polluted continental boundary layer (CBL) levels.

\begin{tabular}{|c|c|c|c|c|c|c|c|c|c|c|}
\hline Layer ID & $\begin{array}{l}\text { Start Time, } \\
\text { UTC s of day }\end{array}$ & $\begin{array}{l}\text { Stop Time, } \\
\text { UTC s of day }\end{array}$ & $\begin{array}{l}\text { Altitude, } \\
\text { km a.s.l. }\end{array}$ & 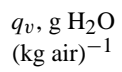 & $\begin{array}{c}\Delta \mathrm{CO} \\
\mathrm{nmol} \mathrm{mol}^{-1}\end{array}$ & $\begin{array}{c}\sigma_{a p}, \mathrm{Mm}^{-1} \\
(550 \mathrm{~nm})\end{array}$ & $\begin{array}{c}\mathrm{BC}_{e} \\
\mathrm{ng} \mathrm{sm}^{-3}\end{array}$ & $\begin{array}{l}\text { PM 2.5, } \\
\mu \mathrm{g} \mathrm{sm}^{-3}\end{array}$ & $\begin{array}{c}\mathrm{BC}_{e} / \mathrm{CO}, \\
\mathrm{mg} \mathrm{BC}(\mathrm{g} \mathrm{CO})^{-1}\end{array}$ & $\begin{array}{c}\mathrm{BC}_{e} / \mathrm{PM} 2.5, \\
\%\end{array}$ \\
\hline \multicolumn{11}{|l|}{$\begin{array}{l}\text { FF } \\
\text { peak data }\end{array}$} \\
\hline 040722aL5 & 11:39:15 & $11: 40: 25$ & 3830 & 0.82 & 179 & 8.1 & 1609 & 21 & 7.5 & 7.7 \\
\hline 040722aL6 & $11: 41: 35$ & $11: 42: 45$ & 3828 & 0.56 & 181 & 6.2 & 1238 & 21 & 5.7 & 5.9 \\
\hline 040722bL4 & $16: 20: 20$ & $16: 24: 20$ & 5730 & 0.19 & 212 & 3.2 & 782 & 34 & 3.1 & 2.3 \\
\hline 040722bL5 & $16: 24: 30$ & $16: 27: 02$ & 5731 & 0.17 & 158 & 3.5 & 837 & 27 & 4.4 & 3.1 \\
\hline $040723 \mathrm{aL} 4^{2)}$ & $12: 58: 20$ & $12: 59: 50$ & 4795 & 1.04 & 185 & 7.7 & 1659 & 39 & 7.4 & 4.3 \\
\hline $040723 \mathrm{aL} 5^{2)}$ & $13: 01: 40$ & 13:03:35 & 4794 & 1.08 & 190 & 7.0 & 1505 & 39 & 6.9 & 3.9 \\
\hline $040723 \mathrm{aL} 6^{2)}$ & $13: 05: 20$ & 13:06:00 & 5418 & 1.56 & 146 & 4.9 & 1134 & 39 & 6.4 & 2.9 \\
\hline \multicolumn{11}{|l|}{$\begin{array}{l}\text { FT } \\
\text { average data }\end{array}$} \\
\hline 040719aL2 & $10: 23: 45$ & $10: 31: 20$ & 4492 & 0.44 & 21 & $<0.1$ & n.d. & & & \\
\hline 040722aL7 & $11: 48: 15$ & $11: 49: 25$ & 1938 & 4.32 & 6 & 0.3 & 44 & 0.8 & 5.6 & \\
\hline 040722bL2 & $15: 58: 20$ & $16: 01: 40$ & 4159 & 0.27 & 35 & $<0.1$ & n.d. & 5 & & \\
\hline 040722bL3 & $16: 05: 40$ & $16: 10: 40$ & 1953 & 5.02 & 22 & 0.8 & 132 & 1.4 & 4.9 & \\
\hline 040723aL2 & $12: 44: 35$ & $12: 47: 50$ & 2915 & 3.98 & 14 & 0.5 & 85 & 9 & 4.9 & \\
\hline 040723aL7 & $13: 22: 20$ & $13: 42: 10$ & 8240 & 0.274 & 33 & $<0.1$ & n.d. & 5 & & \\
\hline 040725aL2 & 15:05:50 & 15:11:00 & 8522 & 0.206 & 1 & $<0.1$ & n.d. & & & \\
\hline 040725bL2 & $18: 30: 00$ & $18: 34: 10$ & 4788 & 2.13 & 6 & $<0.1$ & n.d. & & & \\
\hline 040725bL5 & 18:50:10 & $18: 51: 32$ & 8602 & 0.25 & 10 & $<0.1$ & n.d. & & & \\
\hline 040726aL1 & $15: 19: 10$ & $16: 15: 00$ & 5007 & 1.79 & 25 & $<0.1$ & n.d. & & & \\
\hline \multicolumn{11}{|l|}{$\begin{array}{l}\text { CBL } \\
\text { average data }\end{array}$} \\
\hline 040722bL6 & $16: 50: 20$ & $16: 52: 40$ & 1950 & 9.9 & 19 & 2.8 & 456 & 17.5 & 19.9 & \\
\hline 040722bL7 & $16: 55: 00$ & $16: 56: 40$ & 1626 & 10.1 & 32 & 4.2 & 662 & 18 & 16.9 & \\
\hline 040722bL8 & $16: 56: 40$ & $17: 02: 50$ & 830 & 10.61 & 27 & 5.8 & 853 & 18 & 26.2 & \\
\hline 040723aL0 & $15: 55: 50$ & $16: 03: 45$ & 698 & 9.8 & 35 & 4.5 & 654 & 20 & 15.6 & \\
\hline Emission $^{3)}$ & & & & & & & & & $5.2 \pm 2.5$ & $4.3 \pm 2.5$ \\
\hline
\end{tabular}

1) The compiled data represent a sub-set of all 54 constant-altitude flight legs probed during ITOP, all forest fire smoke plumes are represented, FT and BL levels are shown exemplary; equivalent black carbon $\mathrm{BC} e$ is calculated from $\sigma_{a p}$ using a mass-specific absorption cross-section of $8 \mathrm{~m}^{2} \mathrm{~g}^{-1}$; PM 2.5 is calculated from number size distributions assuming a density of $1400 \mathrm{~kg} \mathrm{~m}^{-3}$ and spherical particle shape; a value of $10 \mathrm{~m}^{2} \mathrm{~g}^{-1}$ reduces the ratio $\mathrm{BC}_{e} / \mathrm{PM} 2.5$ by $20 \%$; n.d. $\rightarrow$ not detected.

2) Lagrangian forest fire plume case with DC 8 (18 July) and BAe 146 (20 July) (Methven et al., 2006).

3) Data taken from Andreae and Merlet (2001).

descent of the aircraft. Since for those levels with varying pressure, the absorption coefficient is not available, these sequences are not considered here. However, size distributions measured during these smoke plume profiles are added to Table 6 .

\subsubsection{Microphysical properties}

The properties of forest fire smoke particles can be represented in a multi-dimensional parameter space. The key parameter combinations investigated here are (1) the number concentration of Aitken mode vs. number concentration of accumulation mode, (2) the mixing state of Aitken mode vs. accumulation mode expressed as the fraction of particles containing non-volatile cores for each mode, (3) $\Delta \mathrm{CO}$ vs. $\left[\mathrm{N}_{\text {nonvol AITK }} / \mathrm{N}_{\mathrm{AITK}}\right] \times\left[\mathrm{N}_{\mathrm{ACC}} / \mathrm{N}_{\text {TOTAL }}\right]$, with $\left[\mathrm{N}_{\text {nonvol AITK }} / \mathrm{N}_{\text {AITK }}\right] \times\left[\mathrm{N}_{\mathrm{ACC}} / \mathrm{N}_{\text {TOTAL }}\right] \rightarrow 1$ for an internally mixed aerosol which is dominated by the ACC mode, and (4) the thermodynamic properties of the forest fire smoke plumes expressed as specific humidity $q_{v}$ and equivalent potential temperature $\theta_{e}$.
Figure 8 shows the distribution of parameter combinations for all aerosol populations observed during ITOP in the "clean" FT and UT (filled grey symbols) and for the peak forest fire smoke plumes (black symbols). The forest fire smoke aerosol represents an extreme case for each investigated aerosol microphysical parameter combination when all ITOP data are considered:

- Figure 8, top left panel: Forest fire smoke particles cluster along the 1:1 line with respect to $\left(\mathrm{N}_{\mathrm{NUC}}+\mathrm{N}_{\mathrm{AITK}}\right)$ vs. $\mathrm{N}_{\mathrm{ACC}}$, while the bulk data set satisfies $\left(\mathrm{N}_{\mathrm{NUC}}+\mathrm{N}_{\mathrm{AITK}}\right) \geq 10 \times \mathrm{N}_{\mathrm{ACC}}$, i.e., forest fire particles are enriched in the accumulation mode while nucleation and Aitken mode are depleted (top left panel).

- Figure 8, bottom left panel: Aged forest fire particles cluster at $f_{\text {Nonvol,AITK }} \cong 1$ and $f_{\text {Nonvol,ACC }} \cong 1$. Almost all particles contain a non-volatile core even in the Aitken mode size range with non-volatile fractions close to unity, i.e., all particles are entirely internally mixed. 
Table 6. Size distribution parameters number concentration N, count median diameter CMD, geometric standard deviation GSD of accumulation and coarse mode forest fire aerosols; data refer to ITOP and LACE 98 observations and near-source size distributions recommended for global climate models (Dentener et al, 2006; Reid et al., 2005b); plume age $\tau$ from FLEXPART analyses is added for the ITOP cases.

\begin{tabular}{|c|c|c|c|c|}
\hline Type of aerosol & $\mathrm{N}, \mathrm{cm}^{-3}$ & $\mathrm{CMD}, \mu \mathrm{m}$ & GSD & Reference \\
\hline North American Flaming & & & & (Einfeld et al., 1991) \\
\hline Mode 1 & 10000 & 0.118 & 1.6 & Fresh emissions \\
\hline Mode 2 & 2.5 & 1.20 & 1.8 & \\
\hline Mode 3 & 0.7 & 3.0 & 1.8 & \\
\hline North American Smoldering & & & & (Einfeld et al., 1991) \\
\hline Mode 1 & 2681 & 0.180 & 1.5 & Fresh emissions \\
\hline Mode 2 & 4 & 1.20 & 2 & \\
\hline Mode 3 & 1.7 & 3.30 & 1.8 & \\
\hline North American Young & & & & (Radke et al., 1991) \\
\hline Mode 1 & 70000 & 0.010 & 1.87 & \\
\hline Mode 2 & 160000 & 0.150 & 1.62 & \\
\hline Mode 3 & 1.95 & 1.20 & 1.85 & \\
\hline North American Young & & & & (Reid et al., 2005a) \\
\hline Fine mode & & $0.16 \pm 0.03$ & $1.7 \pm 0.1$ & \\
\hline North American Aged & & & & (Reid et al., 2005a) \\
\hline Fine mode & & $0.20 \pm 0.03$ & $1.55 \pm 0.2$ & \\
\hline LACE 98 aged lower layer & & & & (Fiebig et al., 2003) \\
\hline Mode 1 & $410 \pm 60$ & $0.057 \pm 0.01$ & $2.0 \pm 0.3$ & \\
\hline Mode 2 & $250 \pm 100$ & $0.34 \pm 0.03$ & $1.35 \pm 0.1$ & \\
\hline Mode 3 & $0.7 \pm 1.0$ & $0.9 \pm 0.7$ & $1.9 \pm 0.5$ & \\
\hline LACE 98 aged upper layer & & & & (Fiebig et al., 2003) \\
\hline Mode 1 & $400 \pm 50$ & $0.050 \pm 0.01$ & $2.0 \pm 0.3$ & \\
\hline Mode 2 & $220 \pm 60$ & $0.23 \pm 0.02$ & $1.45 \pm 0.1$ & \\
\hline Mode 3 & $1.0 \pm 1.0$ & $1.0 \pm 0.3$ & $1.7 \pm 0.3$ & \\
\hline 040722AL5L6 & & & & this study, $\tau=6-9 \mathrm{~d}$ \\
\hline Mode 1, STP & 1600 & 0.065 & 1.60 & \\
\hline Mode 2, STP & 750 & $0.26 \pm 0.02$ & $1.30 \pm 0.05$ & \\
\hline Mode 3, STP & 15 & 0.35 & 1.80 & \\
\hline 040722BL4L5 & & & & this study, $\tau=6-9 \mathrm{~d}$ \\
\hline Mode 1, STP & 950 & 0.080 & 1.60 & \\
\hline Mode 2, STP & 900 & $0.27 \pm 0.02$ & $1.31 \pm 0.05$ & \\
\hline Mode 3, STP & 15 & 0.6 & 1.90 & \\
\hline 040723AL4L6 & & & & this study, $\tau=7-10 \mathrm{~d}$ \\
\hline Mode 1, STP & 900 & 0.090 & 1.40 & \\
\hline Mode 2, STP & 800 & $0.30 \pm 0.02$ & $1.30 \pm 0.05$ & \\
\hline Mode 3, STP & 16 & 0.6 & 1.90 & \\
\hline 040725B profile & & & & this study, $\tau=6-9 \mathrm{~d}$ \\
\hline Mode 1, STP & 890 & 0.078 & 1.56 & \\
\hline Mode 2, STP & 350 & 0.26 & 1.31 & \\
\hline Mode 3, STP & 6 & 0.47 & 1.75 & \\
\hline 040726A & & & & this study, $\tau=10-13 \mathrm{~d}$ \\
\hline Mode 1, STP & 1800 & 0.065 & 1.64 & \\
\hline Mode 2, STP & 500 & 0.27 & 1.32 & \\
\hline Mode 3, STP & 14 & 0.47 & 1.82 & \\
\hline 040730A profile & & & & this study, $\tau=4-6 \mathrm{~d}$ \\
\hline Mode 1, STP & 1300 & 0.085 & 1.90 & \\
\hline Mode 2, STP & 850 & $0.23 \pm 0.02$ & $1.39 \pm 0.05$ & \\
\hline Mode 3 , STP & 1.5 & 0.9 & 1.70 & \\
\hline
\end{tabular}



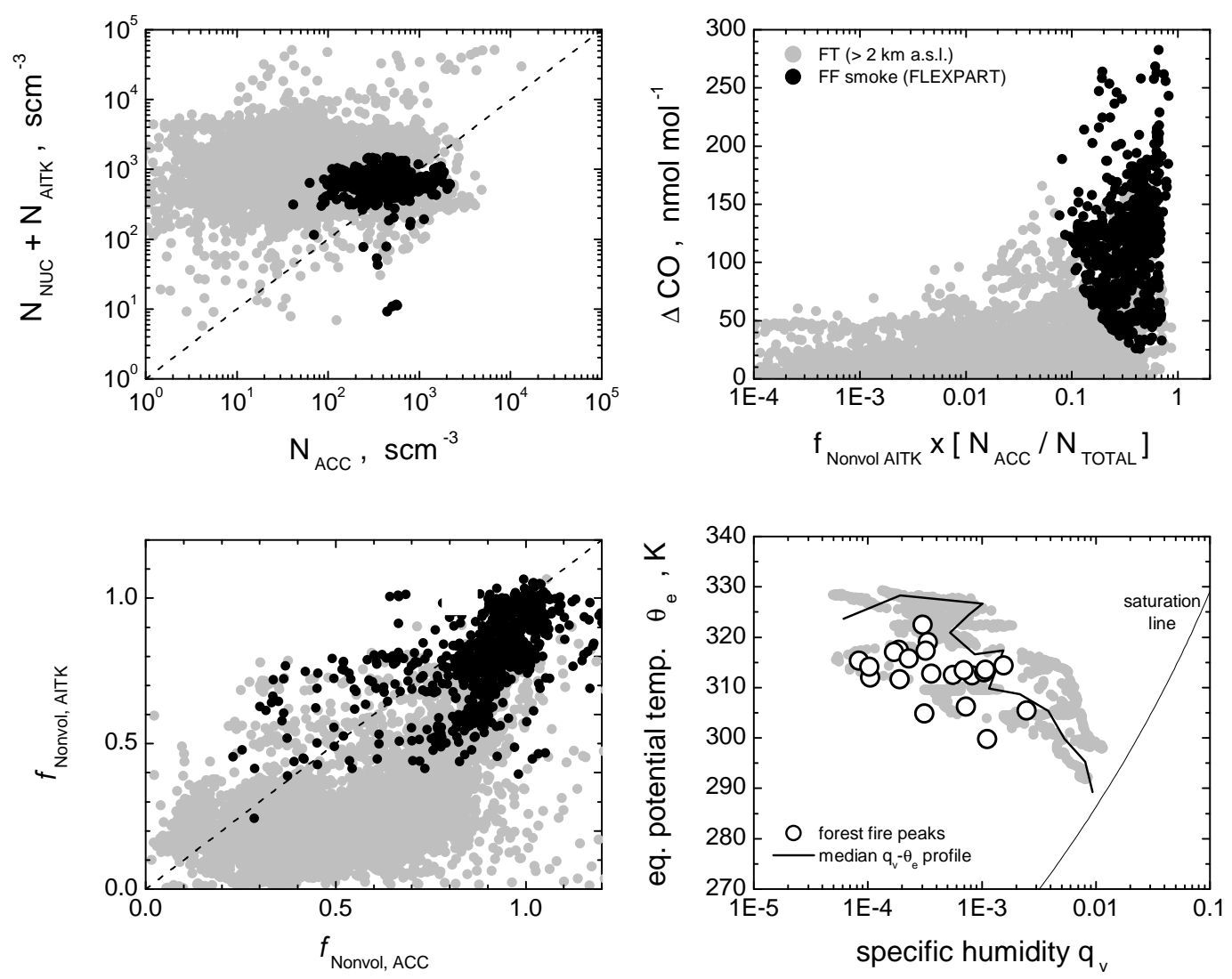

Fig. 8. Properties of forest fire aerosols compared to the entire ITOP FT aerosol data set; top left: number concentration of nucleation (NUC) and Aitken (AITK) mode vs. accumulation mode (ACC); bottom left: non-volatile fraction of Aitken mode vs. accumulation mode; top right: excess $\mathrm{CO}(\triangle \mathrm{CO})$ vs. fraction of non-volatile AITK particles times number fraction of ACC mode; bottom right: thermodynamic properties of aerosol layers. Free troposphere $(\mathrm{FT})$ data $(2-8 \mathrm{~km})$ outside of smoke plumes are neglected since no clear separation from air masses inside of smoke plumes was possible.

- Figure 8, top right panel: Smoke plume characteristics like a dominant ACC mode with $\mathrm{N}_{\mathrm{ACC}} \cong \mathrm{N}_{\mathrm{NUC}}+\mathrm{N}_{\mathrm{AITK}}$ combined with an internal mixture with $f_{\mathrm{NonVol}, \mathrm{AITK}} \cong f_{\mathrm{NonVol}, \mathrm{ACC}} \cong 1$ are always associated with high values of $\triangle \mathrm{CO}$.

- Figure 8, bottom right panel: When plotting all measured $5 \mathrm{~s}$ averaged data in a parameter space spanned by specific humidity $q_{v}$ and equivalent potential temperature $\theta_{e}$, the forest fire aerosol peak data line up at the lower bound of the $q_{v}$ data set (Fig. 8 bottom right panel). The solid line in the bottom right panel of Fig. 8 represents the median $\theta_{e}-q_{v}$ line for all flights analogous to the median aerosol profiles shown in Figs. 6a and $b$. Forest fire plumes occur in air that is much drier and colder than the median profile of ITOP observations. Data points with higher $\Delta C O$ likely have lower $q_{v}$ since these represent plumes that have experienced less mixing across the Atlantic.

\subsubsection{BC fraction of PM 2.5}

Following a detailed report on the chemical composition of North American boreal forest fire particles from the SCARC (Smoke, Cloud and Radiation) experiment, BC contributes $5 \%$ (smoldering) to $10 \%$ (flaming) by mass for fresh $(<1$ day) smoke aerosol (Martin et al., 1996). Total carbon contributes between 50 and $100 \%$ to total particulate matter. For temperate wildfires, $\mathrm{BC}$ and total carbon (organic plus black carbon) contribute $4-10 \%$ and $50-90 \%$, respectively, to PM 2.5 mass (Andreae and Merlet, 2001; Reid et al., 2005a).

During our studies, no chemical data of the smoke particles were collected. An estimated of the $\mathrm{BC}_{e}$ fraction of total mass is obtained from an analysis of the measured particle size distributions. PM 2.5 mass concentrations are calculated from the parameterised particle size distributions assuming spherical particles of density of $1400 \mathrm{~g} \mathrm{~m}^{-3}$ (Reid et al., 2005a). The results are added to Table 5. The BC mass concentration is reduced by $20 \%$ if a mass-specific absorption cross-section of $10 \mathrm{~m}^{2} \mathrm{~g}^{-1}$ instead of $8 \mathrm{~m}^{2} \mathrm{~g}^{-1}$ is used 

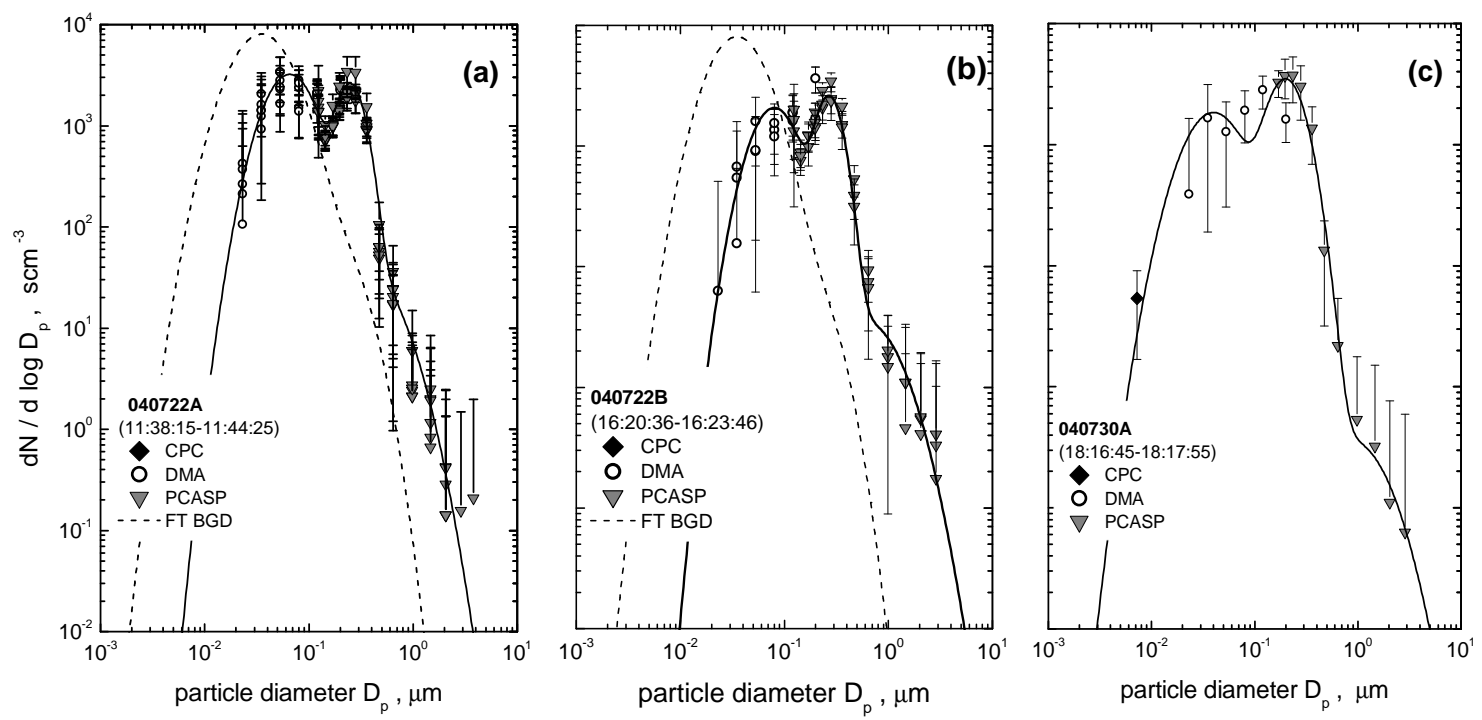

Fig. 9. Composite size distributions in forest fire smoke plumes determined from data of Condensation Particle Counters (CPC), a Differential Mobility Anylaser (DMA), and a Passive Cavity Aerosol Spectrometer Probe (PCASP); mission ID and UTC are given in each plot. Solid lines represent multi-modal log-normal size distributions fitted to the measured data, while the dashed line represents a respective size distribution in the clean UT for the data from 22 July.

for the calculation of $\mathrm{BC}_{e}$ from $\sigma_{a p}$. $\mathrm{BC}$ contributes $2-4 \%$ to PM 2.5 mass, except for the two plumes encountered on Flight $040722 \mathrm{~A}$, where BC contributes 6-8\%. For the ITOP fire smoke plumes which reached Europe on 22-23 July, the $\mathrm{BC}_{e}$ fraction of PM 2.5 is at the lower boundary of values reported for emission conditions. In a very recent publication on the properties of forest fire smoke plumes measured during ICARTT 2004 by the US teams on board of the NASA DC8, Clarke et al. (2007) report an average BC mass fraction of approx. $3 \%$ for aged forest fire smoke particles. Their observations which are based on the chemical analysis of particle samples are in very good agreement with our estimates from size distribution data.

\subsubsection{Size distributions and optical properties}

Figure 9 shows examples of dry size distributions measured during various ITOP forest fire smoke plume encounters on 22 July and 30 July 2004. The size distributions originate from the combined analysis of CPC, DMA and PCASP 100X instrument data. Because the air masses were very dry (relative humidity $<20 \%$ ) no hygroscopic shift was applied to the size distributions. The plumes probed on 22 July were the densest forest fire plume encountered during ITOP with an age of 7-9 days estimated from FLEXPART analyses. The plume probed on 30 July represents a younger plume of an approximate age of 4-6 days after emission. Unfortunately, only size distribution data exist since the plume on 30 July was traversed during decent to the airport of Creil, see also Fig. 4. In all cases key features of the size distributions are the complete depletion of nucleation mode particles, an al- most depleted small Aitken mode and an enhanced accumulation mode compared to the FT background aerosol outside of smoke plumes. An example of a representative FT background size distribution is shown as dashed lines in Fig. 9.

Table 6 compiles the parameters of multi-modal lognormal size distributions fitted to measured composite size distributions. Size distribution parameters recommended for the use in global climate models by AeroCom (Dentener et al., 2006) or reported in a recent review paper (Reid et al., 2005a, b) are added for comparison. Two remarkable differences between ITOP smoke particles and literature data require attention: (1) Radke et al. (1991) and Einfeld et al. (1991) propose a weak coarse mode centred at $1.2-3.3 \mu \mathrm{m}$ for the representation of smoke particles from temperate forest fires, such a mode is not observed in the ITOP cases after one week of atmospheric transport. (2) The accumulation mode observed during ITOP and LACE 98 is located in the diameter range from 0.2 to $0.34 \mu \mathrm{m}$ while size distributions proposed for the use in in climate models show accumulation modes in the size range from 0.12 to $0.20 \mu \mathrm{m}$.

Since BC only contributes $<10 \%$ to the total mass, the absorption of visible light by forest fire smoke particles is weak with a characteristic single scattering albedo of $0.83-$ 0.90 at $\lambda=550 \mathrm{~nm}$ (Martins et al., 1996; Reid et al., 2005b). The ITOP forest fire aerosol probed on 23 July shows a $\mathrm{BC}_{e}$ mass fraction of $4 \%$ (Table 5), resulting in a single scattering albedo of 0.914 (@440 nm) to 0.895 (@600 nm). Optical properties were calculated by Mie theory for a refractive index of $1.55+0.02 i$ and the size distribution 040722AL5L6 from Table 6 (Real et al., 2007). These values fit well into the range of single scattering albedo values determined for for- 
est fire particles. Observed absorption coefficients (@550) range from 3 to $8 \mathrm{Mm}^{-1}$ which is of the order as the values observed for polluted urban outflow from the Paris area.

\section{Discussion}

In the previous section, the properties of aged forest fire smoke layers were described in detail from the observations during ITOP in summer 2004. Although the presented measurements are not the first ones reporting on aerosol properties in smoke plumes after long-range transport (e.g., Petzold et al., 2002; Niemi et al., 2005; Reid et al., 2005a; Müller et al., 2005), they add new aspects to the topic. For the first time, smoke plumes of various age were investigated during one field study. This permits a good comparability of observations. The measured set of parameters included absorption coefficient data, size distribution information covering the entire range of particle sized from $<10 \mathrm{~nm}$ to the super- $\mu \mathrm{m}$ range, and information on the mixing state for several particle size fractions. Combining these extensive aerosol microphysical data with trace gas data particularly for excess $\mathrm{CO}$, several important scientific questions can be tackled. First conclusions drawn from the observations are discussed in this section. They emphasise the BC export efficiency from the source regions and the aerosol transformation processes during atmospheric transport.

The first question of relevance arising is: How efficient is carbonaceous matter transported from fire regions in North American boreal forests to Europe? Following Park et al. (2005), the ratio $\left[\mathrm{BC}_{e} / \Delta \mathrm{CO}\right]_{\text {farfield }}$ observed in the far field to $\left[\mathrm{BC}_{e} / \Delta \mathrm{CO}\right]_{\text {source }}$ determined near the source can be interpreted as a measure for the efficiency of the atmospheric export of $\mathrm{BC}$ from a source region. Wet removal processes mainly influence the particle phase (BC) while $\Delta \mathrm{CO}$ remains almost unaffected. Park et al. report a significant decrease in the ratio $\left[\mathrm{BC}_{e} / \Delta \mathrm{CO}\right]_{\text {farfield }} \times\left[\mathrm{BC}_{e} / \Delta \mathrm{CO}\right]_{\text {source }}^{-1}$ with altitude for anthropogenic $\mathrm{BC}$ in Asian outflow. The interpretation suggests that the removal of $\mathrm{BC}$ during uplifting reduces the efficiency of the transport of $\mathrm{BC}$ to altitudes which are relevant for intercontinental transport.

Figure 10 shows the observed emission ratios $\left[\mathrm{BC}_{e} / \Delta \mathrm{CO}\right]_{\text {farfield }}$ for forest fire smoke plumes. The values are plotted as average values over the analysed flight-sequences and as peak values in the strongest parts of the plumes together with the emission value from Andreae and Merlet (2001). Almost all values observed during ITOP fall into the range of uncertainty spanned by the Andreae and Merlet data. The only plumes showing $\left[\mathrm{BC}_{e} / \Delta \mathrm{CO}\right]_{\text {farfield }}<\left[\mathrm{BC}_{e} / \Delta \mathrm{CO}\right]_{\text {source }}$ are 040722bL4 and 040723aL6. Interpreting the ratio $\left[\mathrm{BC}_{e} / \Delta \mathrm{CO}\right]_{\text {farfield }} \times\left[\mathrm{BC}_{e} / \Delta \mathrm{CO}\right]_{\text {source }}^{-1}$ as an export efficiency, the majority of plumes is exported with $90 \%$ efficiency. Efficiencies of $30 \%$ and $50 \%$ can be attributed to plumes 040722bL4 and 040723aL6. Assuming a mass-specific

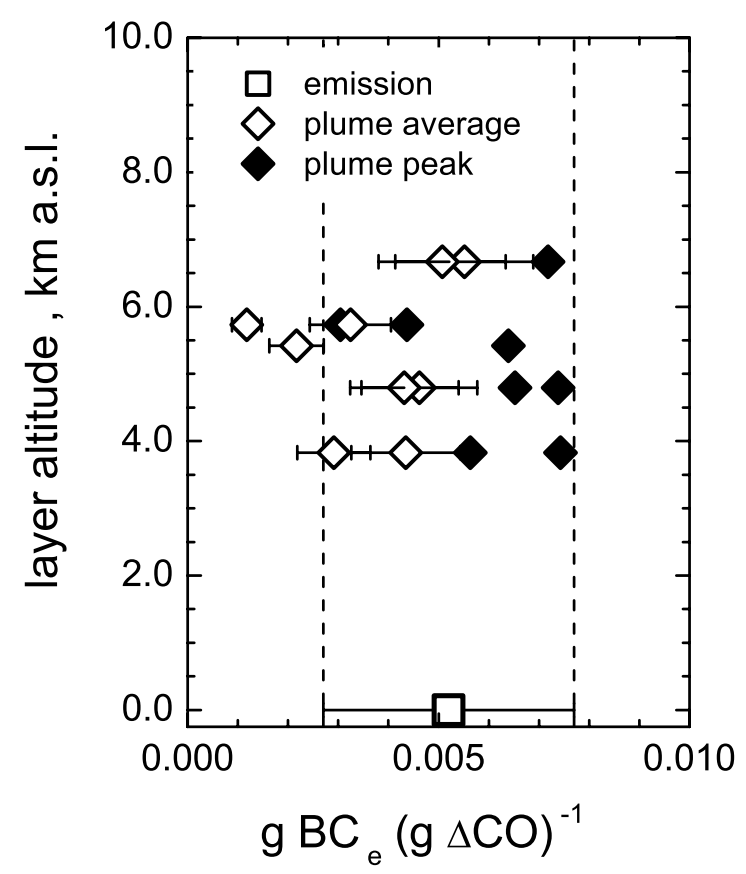

Fig. 10. Ratio of equivalent $\mathrm{BC}_{e}$ per excess $\mathrm{CO}$; the emission value is taken from Andreae and Merlet (2001), open symbols represent layer-averaged values measured during ITOP, filled refer to maximum values inside a plume.

absorption cross-section of $10 \mathrm{~m}^{2} \mathrm{~g}^{-1}$ instead of $8 \mathrm{~m}^{2} \mathrm{~g}^{-1}$, the export efficiencies are $>70 \%$ for the bulk of the investigated plumes, and $24 \%$ and $40 \%$, respectively, for plumes 040722bL4 and 040723aL6. Concluding, removal of BC from boreal forest fires during transport seems to play only a minor role for the investigated cases. More than $\frac{3}{4}$ of the emitted $\mathrm{BC}$ has entered the region for intercontinental transport at higher altitudes.

This interpretation is supported by the present knowledge on injection heights of boreal forest fire plumes. Lavoué et al. (2000) estimate an injection height of $\geq 6000 \mathrm{~m}$ for boreal forest fires depending on the frontal fire intensity. The AeroCom emission data set (Dentener et al., 2006) assumes that $40 \%$ of Canadian boreal fire plumes are injected at heights of 3000-6000 $\mathrm{m}$ a.s.1.. In recent studies of the summer 2004 fires, (Leung et al., 2006; Morris et al., 2006) injection heights of 3000-6000 m a.s.l. are reported from model and trajectory data analyses. The vertical distribution of injection heights for boreal forest fire plumes is given by Turquety et al. $(2006,2007)$ as $40 \% \mathrm{BL}, 35 \% \mathrm{MT}(600-400 \mathrm{hPa})$, and $25 \%$ UT (400-200 hPa).

The smoke plumes may reach FT altitudes without major removal of particles by precipitation, which results in a high export efficiency for boreal forest fire smoke plumes. For smoky clouds over the Amazon, Andreae et al. (2004) proposed that the high concentration of potential $\mathrm{CCN}$ creates a high concentration of small cloud droplets and prohibits 


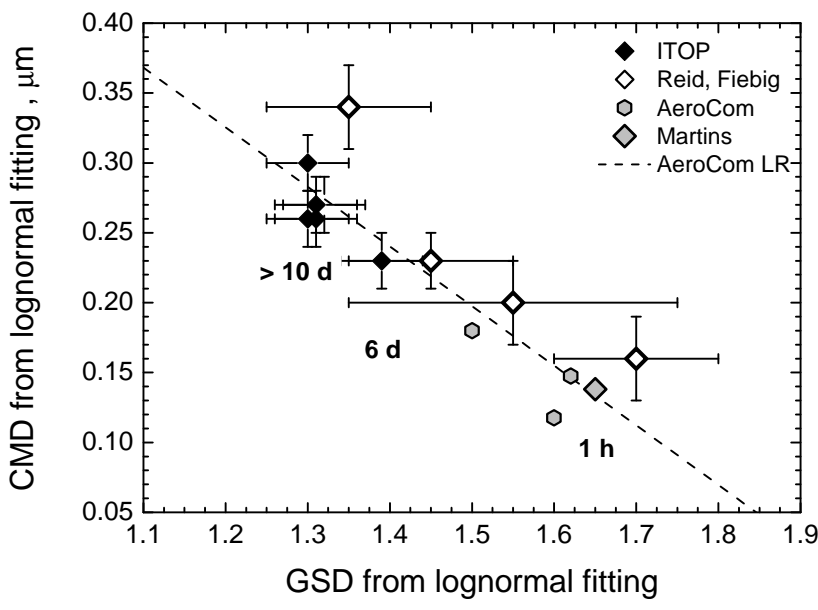

Fig. 11. Count median diameter (CMD) of the size distribution of boreal forest fire smoke aerosol as a function of the geometric standard deviation (GSD) of the distribution; data are taken from Reid et al. (2005a), Fiebig et al. (2003), the AeroCom data set (Dentener et al., 2006), this study, and Martins et al. (1996) for fresh aerosol. The dashed line AeroCom LR corresponds to the regression analysis for the AeroCom data set with $\mathrm{CMD}=(837.27-426.51 \times \mathrm{GSD}) / 1000$ (Dentener et al., 2006).

precipitation. Particles are kept in the air and can enter the long-range transport altitude regime where the particles are released as aerosol after the cloud droplets have been evaporated. Combined with the injection of plumes at higher altitudes, a similar process may explain the high export efficiency for boreal forest fire plumes.

Plume dilution may shed light on the horizontal and vertical spreading of the plume during atmospheric transport. For the particular flight sequences $040723 \mathrm{aL} 4$ to $040723 \mathrm{aL} 6 \mathrm{La}-$ grangian match conditions are fulfilled with respect to flights of NASA DC8 on 18 July and BAe 146 FAAM aircraft on 20 July (Methven et al., 2006). Assuming an average CO mixing ratio in the FT of $90 \mathrm{nmol} \mathrm{mol}^{-1}$, the measured CO mixing ratios of $448.7 \mathrm{nmol} \mathrm{mol}^{-1}$ (DC 8), $415.4 \mathrm{nmol} \mathrm{mol}^{-1}$ (BAe-146) and $242.5 \mathrm{nmol} \mathrm{mol}^{-1}$ (Falcon) suggest plume dilutions by a factor of 1.1 from 18-20 July and by a factor of 2.1 from 20-23 July. Trajectory calculations by Real et al. (2007) show a reduction of CO from $450 \mathrm{nmol} \mathrm{mol}^{-1}$ on 18 July to $250 \mathrm{nmol} \mathrm{mol}^{-1}$ on 22 July which suggests a plume dilution factor of 1.8. Plume dilution by a factor of $2.0 \pm 0.2$ over a period of 4 days demonstrates that the plumes move across the North Atlantic in a very confined mode.

Another key question focuses on the transformation of smoke aerosols during long-range transport. After 1-2 weeks of atmospheric transport, the observed size distributions differ significantly from the values recommended for the use in global climate models (Dentener et al., 2006) which consist of particles of larger sizes but with lower number concentrations than observed during ITIOP. However, the observed size distributions fit well into the picture of size distribu- tion modification processes in fire plumes. Figure $11 \mathrm{com}-$ piles the size distribution parameters count median diameter (CMD) and geometric standard deviation (GSD) for fresh and aged boreal forest fire aerosols. Dentener et al. (2006) reported a linear relation between CMD and GSD for wildfire aerosols. Our data extend the data set to plume ages beyond one week showing, that the modification of size distributions is still active.

As is discussed by Hinds (1999), coagulation will narrow size distributions with time by enhanced coagulation of smaller particles with larger particles. With the absence of gaseous precursors, particle nucleation is inhibited resulting in a suppressed supply of nucleation mode particles to the coagulation process. The net result is an increase of the modal diameter and a narrowing of the size distribution of the ACC mode. Hinds points out that a self-preserving size distribution which describes a steady state of the aerosol is characterised by GSD values of 1.32-1.34. This picture is in close agreement with our analyses. Furthermore, similar observations are reported by Müller et al. (2007) who analysed lidar observations of well-aged forest fire plumes. They concluded that the effective diameter of the smoke particles increases until an approximate plume age of 10-15 days. Then, a steady state of the aerosol size distribution is reached.

\section{Conclusions}

During the 2004 ICARTT-ITOP study an extensive set of observations was collected for boreal forest fire smoke plumes after transport from North America to Europe. The presented data analysis shows that $\mathrm{BC}$ from forest fires can be transported very efficiently on intercontinental scales. Physicochemical properties of aged particles such as $\mathrm{BC}_{e} / \Delta \mathrm{CO}$ fall into the range of uncertainty spanned by the respective values for fresh emissions. The BC export efficiencies are $>70$ $90 \%$ for the bulk of the investigated plumes. Only for two cases, these efficiencies are $<50 \%$. The forest fire aerosol is characterised by a strong accumulation mode, an almost depleted nucleation mode, and by an entirely internal mixture even for Aitken mode particles. Very dry air masses (low specific humidity) turned out to be typical for the forest fire plumes observed. While the median diameter of the accumulation mode growths with plume age, the size distribution becomes narrower (GSD decreases). This behaviour of the size distribution is typical for coagulation in an aerosol without ongoing particle nucleation. This finding also agrees with recently published lidar observations (Müller et al., 2007). The BC transported in such plumes increases the aerosol absorption coefficient by about two orders of magnitude above the European free troposphere background level. The impact of such strong fire plumes on optical and radiative properties of the free troposphere aerosol above Europe is subject of ongoing work. 


\section{Appendix A}

\section{Data analysis procedure}

\section{A1 PSAP data}

The Particle Soot Absorption Photometer PSAP data were used to infer absorption coefficients $\sigma_{a p}$ and BC mass concentrations $\mathrm{BC}_{e}$ in the FT. From previous experience (Petzold et al., 2002), only constant-altitude flight sequences outside of cloud were analysed. This reduction of data analysis avoids measurement artefacts due to pressure changes in the sampling line during ascent and descent of the aircraft between different flight levels. The limitation to outof-cloud sequences excludes measurement artefacts due to humidity-effects on the filter transmission function (Arnott et al., 2003). The scattering and filter loading correction function proposed by Bond et al. (1999) was applied. Since no direct measurement of the aerosol light scattering coefficient was available, the scattering coefficient was calculated from the particle size distributions using an estimate for the complex refractive index which matched the observations. This approach is described extensively by Fiebig et al. (2002).

The data analysis used a $20 \mathrm{~s}$ moving average for smoothing the scattered PSAP raw data. This averaging time was found to smooth the data sufficiently while keeping the timeresolution at a reasonable level. The detection limit of the method was set empirically to $0.1 \mathrm{sMm}^{-1}$ based on experience from earlier applications during airborne studies (Petzold et al., 2002). Similar to the MAAP data from the mountain sites, the aerosol absorption coefficient $\sigma_{a p}(\lambda=550 \mathrm{~nm})$ was converted to an equivalent $\mathrm{BC}$ mass concentration $\mathrm{BC}_{e}$ (Andreae and Gelencser, 2006) by applying a mass-specific absorption cross-section of $8 \mathrm{~m}^{2} \mathrm{~g}^{-1}$ (Bond and Bergstrom, 2006).

\section{A2 Number concentration data}

The number concentrations of NUC, AITK and ACC mode particles were determined from CPC data and from PCASP100X data. Although all instruments report $1 \mathrm{~Hz}$ data, the time series were calculated for a time resolution of $5 \mathrm{~s}$ to avoid instrument response time effects. CPC instruments were operated at nominal minimum threshold diameters (50\% response probability) $D_{p, 50 \%}=5 \mathrm{~nm}, 14 \mathrm{~nm}$, and approx. $80 \mathrm{~nm}$. The latter $D_{p, 50 \%}$ was achieved by operating one CPC with $D_{p, 50 \%}=14 \mathrm{~nm}$ and equipped with a diffusionscreen separator consisting of 3 screens, which shifts $D_{p, 50 \%}$ to $80 \mathrm{~nm}$ at FT conditions of approx. $300 \mathrm{hPa}$ (Feldpausch et al., 2006).

$\mathrm{N}_{\mathrm{NUC}}$ is defined as the difference of the number concentrations detected by the CPCs with $D_{p, 50 \%}=5 \mathrm{~nm}$ and $D_{p, 50 \%}=14 \mathrm{~nm}, \mathrm{~N}_{\text {AITK }}$ is defined as the number concentration detected by the CPC with $D_{p, 50 \%}=14 \mathrm{~nm}$, and $\mathrm{N}_{\mathrm{ACC}}$ is defined as the total number of particles counted by the PCASP instrument which has a nominal size range of $0.1 \mu \mathrm{m} \leq D_{p} \leq 3 \mu \mathrm{m}$.

For the fast identification of layers of ACC modedominated internally mixed aerosols from time series of aerosol number concentrations, the product of $\left[\mathrm{N}_{\text {nonvolAITK }} / \mathrm{N}_{\mathrm{AITK}}\right] \times\left[\mathrm{N}_{\mathrm{ACC}} / \mathrm{N}_{\mathrm{TOTAL}}\right]$ was evaluated. The ratio $\mathrm{N}_{\text {nonvolAITK }} / \mathrm{N}_{\text {AITK }}$ describes the number fraction of particles in the AITK mode which contain non-volatile compounds. The review paper by Raes et al. (2000) on the formation and cycling of the aerosol in the global atmosphere shows that non-volatile particle compounds can be related to salts, soil and dust components and to carbonaceous compounds, which are all observed in samples of aged aerosols. During long-range transport coagulation processes are expected to cause a complete internal mixture of these components. Fresh nucleation mode particles will most likely occur in an external mixture. The factor $\mathrm{N}_{\mathrm{ACC}} / \mathrm{N}_{\text {TOTAL }}$ reflects the contribution of ACC to the total aerosol by number. Schröder et al. (2002) reported different aerosol states which are observed in the northern-hemispheric mid-latitude FT aerosol: Active particle nucleation corresponds to a depleted ACC mode and $\mathrm{N}_{\mathrm{ACC}} \ll \mathrm{N}_{\mathrm{TOTAL}}$ $\left(\left[\mathrm{N}_{\text {nonvolAITK }} / \mathrm{N}_{\mathrm{AITK}}\right] \times\left[\mathrm{N}_{\mathrm{ACC}} / \mathrm{N}_{\mathrm{TOTAL}}\right] \rightarrow 0\right)$ while well aged FT aerosol is characterised by suppressed particle nucleation and a strong ACC mode with $\mathrm{N}_{\mathrm{ACC}} \cong \mathrm{N}_{\mathrm{TOTAL}}$ $\left(\left[\mathrm{N}_{\text {nonvolAITK }} / \mathrm{N}_{\mathrm{AITK}}\right] \times\left[\mathrm{N}_{\mathrm{ACC}} / \mathrm{N}_{\mathrm{TOTAL}}\right] \rightarrow 1\right)$.

\section{A3 Size distribution data}

Size distributions were inferred from a combined analysis of DMA and PCASP-100X data. The DMA was operated in the stepping mode at diameters $0.015,0.023,0.035,0.053,0.08$, 0.12 , and $0.2 \mu \mathrm{m}$ at ambient pressure. At each diameter, the instrument was kept for $10 \mathrm{~s}$ which gives a total measurement cycle of $70 \mathrm{~s}$ for one size distribution. For the data analysis the first $5 \mathrm{~s}$ of data per diameter were skipped to avoid relaxation effects during the variation of the DMA set-diameter. The data analysis used the algorithm described by Reischl (1991).

Time series of the accumulation and coarse mode aerosol volume were calculated from PCASP-100X data, assuming spherical particle shape. Outside of forest fire smoke plumes, PCASP-100X (operation wavelength $\lambda=632 \mathrm{~nm}$ ) size distributions were determined using a refractive index $m=1.53+0.0 i$ (ammonium sulphate) for tropospheric air masses and $m=1.40+0.0 i$ (sulphuric acid) for the tropopause region (Petzold et al., 2002). In the case of forest fire smoke plumes, complex refractive indices of $1.53+0.0 i$ for the scattering component (Haywood et al., 2003) and 2.00+0.63i for the absorbing component (Ackerman and Toon, 1981) were considered reasonable assumptions. Using the volumeweighting of refractive indices method (Chylek et al., 1981), an aerosol containing $5 \%(10 \%)$ of $\mathrm{BC}$ by volume is described by a complex refractive index of $1.553+0.032 i$ $(1.577+0.063 i)$. Both refractive indices were used for the 
size distribution inversion in forest fire plume probes. PM 2.5 time series were inferred from the aerosol volume by assuming unit particle density of $1400 \mathrm{~kg} \mathrm{~m}^{-3}$ which is typical for particulate organic matter (Reid et al., 2005a). The FSSP300 data were mainly used for the identification of in-cloud sequences. If the number concentration in the cloud mode $\left(D_{p}>3 \mu \mathrm{m}\right)$ exceeded $1 \mathrm{~cm}^{-3}$, sequences were labelled incloud.

While the PCASP and the FSSP 300 instruments were operated at wing stations outside the aircraft cabin, the CPC instruments and the DMA were operated inside the aircraft cabin. The used aerosol inlet is described by Fiebig (2001). The aerosol inlet contains two sampling lines. The line used for sampling NUC and AITK mode particles samples directly from the atmosphere without deceleration of the probe. From previous work we know that the maximum cut-off diameter of this line is approx. $0.1 \mu \mathrm{m}$ at $8000 \mathrm{~m}$ a.s.l. (Fiebig, 2001). The DMA and the PSAP were connected to an isokinetic sampling line behind a deceleration cone which has an approx. cut-off diameter of $3 \mu \mathrm{m}$ (Petzold et al., 2002). These inlet features justify the definition of $\mathrm{N}_{\mathrm{AITK}}=\mathrm{N}(\mathrm{CPC}$, $\left.D_{p, 50 \%}=14 \mathrm{~nm}\right)$ and $\mathrm{N}_{\mathrm{ACC}}=\mathrm{N}(\mathrm{PCASP}-100 \mathrm{X})$, since the instruments have only a limited overlap region with respect to detection diameters.

\section{A4 Volatility analysis}

The number fractions of volatile particles of the NUC mode, AITK mode and ACC mode were determined from two CPC instruments connected to heated and non-heated sampling lines of equal lengths. The CPC instrument pair sensitive to AITK particles was set to $D_{p, 50 \%}=14 \mathrm{~nm}$. The heating temperature was set to $250^{\circ} \mathrm{C}$ for separating volatile components of sulphuric acid-like and ammonium sulphate-like behaviour from non-volatile or refractory particle components like BC, sea salt, dust and soil material (e.g., Engler et al., 2006). A similar configuration was used for the determination of the volatile fraction of NUC mode particles using two CPC with $D_{p, 50 \%}=5 \mathrm{~nm}$. The volatile fraction of the ACC mode was determined from another two CPC equipped with diffusion screen separators containing 3 screens each.

\section{A5 Excess CO}

For all ITOP flights, "excess-CO" $(\Delta \mathrm{CO})$ was calculated from measured $\mathrm{CO}$ mixing ratios. First a minimum $\mathrm{CO}$ profile was constructed for every flight to represent "undisturbed" background CO conditions. For every $250 \mathrm{~m}$ altitude bin of the flight, the minimum CO mixing ratio was estimated for conditions outside of pollution plumes and composed to a vertical profile. For every flight the estimated minimum $\mathrm{CO}$ profile was extrapolated to altitudes along the flight track and excess- $\mathrm{CO}$ was calculated by subtracting minimum $\mathrm{CO}$ from measured CO. Since the types of air masses changed from day to day it was necessary to estimate a minimum $\mathrm{CO}$ profile for every flight. In general, minimum CO mixing ratios varied between 70 and $90 \mathrm{nmol} \mathrm{mol}^{-1}$ in the free troposphere. Occasionally, subtropical air masses with very low CO mixing ratios $\left(50-60 \mathrm{nmol} \mathrm{mol}^{-1}\right)$ reached the operation area.

\section{A6 Thermodynamic air mass properties}

Equivalent potential temperature $\theta_{e}$ and specific humidity $q_{v}$ were calculated according to the procedure described by Bolton (1980) and Methven et al. (2003). In general, $\theta_{e}$ varies slowly with height and a positive gradient indicates stability to moist and dry convection. In contrast, $q_{v}$ varies across several orders of magnitude. Following Methven and co-workers and the references given there, $\theta_{e}$ and $q_{v}$ are approximately conserved for reversible adiabatic processes in unsaturated air masses. These parameters may thus serve as good thermodynamic markers for air masses and describe their thermodynamic history. The thermodynamic classification becomes relevant particularly in those cases when Lagrangian studies are performed (Methven et al., 2006). Our discussion mainly focuses on the question whether forest fire smoke plumes show distinctly different thermodynamic properties than air masses not affected by forest fire plumes.

Acknowledgements. Part of this work was supported by the Deutsche Forschungsgemeinschaft within the project SAMUM under Contract No. Pe 632/2-1. An important contribution to the presented results is part of $\mathrm{B}$. Weinzierl's $\mathrm{PhD}$ thesis. We are grateful to P. Feldpausch, H. Rüba, M. Lichtenstern and the entire Falcon flight operations team from DLR for their valuable contributions during the ITOP field experiment. The contributions of SCAVEX data by A. Minikin from DLR, BC data from Hohenpeissenberg by U. Kaminski from DWD, and of the AeroCom parameter sets by F. Dentener and L. Marelli from JRC Ispra are appreciated. Fruitful discussions during the data analysis process with $\mathrm{H}$. Coe, University of Manchester, J. Methven, University of Reading, and S. Arnold, University of Leeds, are gratefully acknowledged.

Edited by: R. Vautard

\section{References}

Ackerman, T. P. and Toon, O. B.: Absorption of visible radiation in atmosphere containing mixtures of absorbing and nonabsorbing particles, Appl. Opt., 20, 3661-3668, 1981.

Ackermann, I. J., Hass, H., Memmesheimer, M., Ebel, A., Binkowski, F. S., Shankar, U.: Modal Aerosol Dynamics for Europe: Development and first applications, Atmos. Environ., 32, 2981-2999, 1998.

Andreae, M. O.: Aerosols before pollution, Science, 315, 50-51, doi:10.1126/science.1136529, 2007.

Andreae, M. O. and Gelencser, A.: Black carbon or brown carbon?, Atmos. Chem. Phys., 6, 3131-3148, 2006, http://www.atmos-chem-phys.net/6/3131/2006/.

Andreae, M. O. and Merlet, P.: Emission of trace gases and aerosols from biomass burning, Global Biogeochem. Cy., 15, 955-966, 2001. 
Andreae, M. O., Rosenfeld, D., Artaxo, P., Costa, A. A., Frank, G. P., Longo, K. M., Silva-Dias, M. A. F.: Smoking rain clouds over the Amazon, Science, 303, 1337-1342, 2004.

Arnott, W. P., Moosmüller, H., Sheridan, P. J., Ogren, J. A., Raspet, R., Slaton, W. V., Hand, J. L., Kreidenweis, S. M., and Collett, J.: Photoacoustic and filter-based ambient aerosol light absorption measurements: Instrument comparisons and the role of relative humidity, J. Geophys. Res., 108, 4034, doi:10.1029/2002JD002165, 2003.

Baltensperger, U., Gäggeler, H. W., Jost, D. T., Lugauer, Schwikowski, M., Weingartner, E., and Seibert, P.: Aerosol climatology at the high-Alpine site Jungfraujoch, Switzerland, J. Geophys. Res., 102, 19707-19715, 1997.

Baumgardner, D., Kok, G., and Raga, G.: Warming of the arctic lower stratosphere by light absorbing particles, Geophys. Res. Lett., 31, L06117, doi:10.1029/2003GL018883, 2004.

Bolton, D.: The computation of equivalent potential temperature, Mon. Wea. Rev., 108, 1046-1053, 1980.

Bond, T. C. and Bergstrom, R. W.: Light absorption by carbonaceous particles: An investigative review, Aerosol Sci. Tech., 40, 27-67, 2006.

Bond, T. C., Anderson, T. L., and Campbell, D.: Calibration and intercomparison of filter-based measurements of visible light absorption by aerosols, Aerosol Sci. Tech., 30, 582-600, 1999.

Chylek, P., Ramaswamy, V., Cheng, R., and Pinnik, R.G.: Optical properties and mass concentration of carbonaceous smoke, Appl. Opt., 20, 2980-2985, 1981.

Clarke, A. D., Collins, W. G., Rasch, P. J., Kapustin, V. N., Moore, K., Howell, S., and Fuelberg, H. E.: Dust and pollution transport on global scales: Aerosol measurements and model predictions, J. Geophys. Res., 106(D23), 32 555-32 570, doi:10.1029/2000JD900842, 2001.

Clarke, A. D., Shinouzka, Y., Kapustin, V. N., Howell, S., Huebert, B., Doherty, S., Anderson, T., Covert, D., Anderson, J., Hua, X., Moore II, K. G., McNaughton, C., Carmichael, G., and Weber, R.: Size distributions and mixtures of dust and black carbon aerosol in Asian outflow: Physicochemistry and optical properties, J. Geophys. Res., 109, D15S09, doi:1029/2003JD004378, 2004.

Clarke, A., McNaughton, C., Kapustin, C., et al.: Biomass burning and pollution aerosol over North America: Organic components and their influence on spectral optical properties and humidification response, J. Geophys. Res., 112, D12S18, doi:10.1029/2006JD007777, 2007.

Damoah, R., Spichtinger, N., Forster, C., James, P., Mattis, I., Wandinger, U., Beirle, S., Wagner, T., and Stohl, A.: Around the world in 17 days - hemispheric-scale transport of forest fire smoke from Russia in May 2003, Atmos. Chem. Phys., 4, 13111321, 2004,

http://www.atmos-chem-phys.net/4/1311/2004/.

Damoah, R., Spichtinger, N., Servranckx, R., Fromm, M., Eloranta, E.W., Razenkov, I.A., James, P., Shulski, M., Forster, C., and Stohl, A.: A case study of pyro-convection using transport model and remote sensing data, Atmos. Chem. Phys., 6, 173-185, 2006, http://www.atmos-chem-phys.net/6/173/2006/.

Dentener, F., Kinne, S., Bond, T., Boucher, O., Cofala, J., Generoso, S., Ginoux, P., Gong, S., Hoelzmann, J. J., Ito, A., Marelli, L., Penner, J. E., Putaud, J.-P., Textor, C., Schulz, M., van de Werf, G. R., and Wilson, J.: Emissions of primary aerosol and precur- sor gases for the years 2000 and 1750 , prescribed data sets for AeroCom, Atmos. Chem. Phys., 6, 2703-2763, 2006,

http://www.atmos-chem-phys.net/6/2703/2006/.

Einfeld, W., Ward, D. E., and Hardy, C. C.: Effects of Fire Behaviour on Prescribed Fire Smoke Characteristics: A Case Study, in: Global Biomass Burning: Atmospheric, Climatic, and Biospheric Implications, edited by: Levine, J. S., MIT press, Cambridge, MA, 412-419, 1991.

Engler, C., Rose, D., Wehner, B., Wiedensohler, A., Brüggemann, E., Gnauk, T., Spindler, G., Tuch, T., and Birmili, W.: Size distribution of non-volatile particle residuals $\left(D_{p}<800 \mathrm{~nm}\right)$ at a rural site in Germany and relation to air mass origin, Atmos. Chem. Phys. Discuss., 6, 5505-5542, 2006,

http://www.atmos-chem-phys-discuss.net/6/5505/2006/.

Feldpausch, P., Fiebig, M., Fritzsche, L., and Petzold, A.: Measurement of ultrafine aerosol size distributions by a combination of diffusion screen separators and condensation particle counters, J. Aerosol Sci., 37, 577-597, doi:10.1016/j.jaerosci.2005.04.009, 2006.

Feichter, J., Kjellström, E., Rodhe, H., Dentener, F., Lelieveld, J., and Roelofs, G.-J.: Simulation of the tropospheric sulfur cycle in a global climate model, Atmos. Environ., 30, 1693-1707, 1996.

Fiebig, M.: The tropospheric aerosol at mid-latitudes - microphysics, optics and climate forcing illustrated by the LACE 98 field study, Doctoral thesis Ludwig-Maximilians-University $\mathrm{Mu}-$ nich, DLR Research report FB 2001-23, 259 pp., 2001.

Fiebig, M., Petzold, A., Wandinger, U., Wendisch, M., Kiemle, C., Stifter, A., Ebert, M., Rother, T., and Leiterer, U.: Optical closure for an aerosol column: Method accuracy, and inferable properties applied to a biomass-burning aerosol and its radiative forcing, J. Geophys. Res., 107, 8130, doi:10.1029/2000JD000192, 2002.

Fiebig, M., Stohl, A., Wendisch, M., Eckhardt, S., and Petzold, A.: Dependence of solar radiative forcing of forest fire aerosol on ageing and state of mixture, Atmos. Chem. Phys., 3, 881-891, 2003, http://www.atmos-chem-phys.net/3/881/2003/.

Forster, C., Wandinger, U., Wotawa, G., James, P., Mattis, I., Althausen, D., Simmonds, P., O'Doherty, S., Jennings, S. G., Kleefeld, Ch., Schneider, J., Trickl, T., Kreipl, S., Jäger, H., and Stohl, A.: Transport of boreal forest fire emissions from Canada to Europe, J. Geophys. Res., 106, 22 887-22 906, 2001.

Fromm, M., Alfred, J., Hoppel, K., Hornstein, J., Bevilacqua, R., Shettle, E., Servranckx, R., Li, and Stocks, B.: Observations of boreal forest fire smoke in the stratosphere by POAM III, SAE II, and lidar in 1998, Geophys. Res. Lett., 27, 1407-1410, 2000.

Fromm, M., Bevilacqua, R., Servranckx, R., Rosen, J., Thayer, P. J., Herman, J., and Larko, D.: Pyro-cumulonimbus injection of smoke to the stratosphere: observations and impact of a super blowup in northwestern Canada on 3-4 August 1998, J. Geophys. Res., 110, D08205, doi:10.1029/2004JD005350, 2005.

Haywood, J. M., Osborne, S. O., Francis, P. N., Keil, A., Formenti, P., Andreae, M. O., and Kaye, P. H.: The mean physical and optical properties of regional haze dominated by biomass burning aerosol measured from the C-130 aircraft during SAFARI 2000, J. Geophys. Res., 108, 8473, doi:1029/2002JD002226, 2003.

Hendricks, J., Kärcher, B., Döpelheuer, A., Feichter, J., Lohmann, U., and Baumgardner, D.: Simulating the global atmospheric black carbon cycle: a revisit to the contribution of aircraft emissions, Atmos. Chem. Phys., 4, 2521-2541, 2004, 
http://www.atmos-chem-phys.net/4/2521/2004/.

Hinds, W. C.: Aerosol Technology, 2nd ed., Wiley, New York, 1999. Hsu, N. C., Herman, J. R., Gleason, J. F., Torres, O., and Seftor, C. J.: Satellite detection of smoke aerosols over a snow/ice surface by TOMS, Geophys. Res. Lett., 26, 1165-1168, 1999.

Jost, H.-J., Drdla, K., Stohl, A., Pfister, L., Loewenstein, M., Lopez, J. P., Hudson, P. K., Murphy, D. M., Cziczo, D. J., Fromm, M., Bui, T. P., Dean-Day, J., Gerbig, C., Mahoney, M. J., Richard, E. C., Spichtinger, N., Pittman, J. V., Weinstock, E. M., Wilson, J. C., and Xueref, I.: In-situ observations of midlatitude forest fire plumes deep in the stratosphere. Geophys. Res. Lett. 31, L11101, doi:10.1029/2003GL019253, 2004.

Kasischke, E. S., Hyer, E. J., Novelli, P. C., Bruhwiler, L. P., French, N. H. F., Sukhinin, A. I., Hewson, J. H., and Stock, B. J.: Influences of boreal forest fire emissions onNorthern Hemisphere atmospheric carbon and carbon monoxide, Global Biogeochem. Cy., 19, GB1012, doi:10.1029/2004GB002300, 2005.

Lauer, A., Hendricks, J., Feichter, J., Ackermann, I., Schell, B., Hass, H., and Metzger, S.: Simulating aerosol microphysics with the ECHAM/MADE GCM - Part I: Model description and comparison with observations, Atmos. Chem. Phys., 5, 3251-3276, 2005 ,

http://www.atmos-chem-phys.net/5/3251/2005/.

Lavoué, D., Liousse, C., Cachier, H., Stocks, B. J., and Goldammer, J. G.: Modelling of carbonaceous particles emitted by boreal and temperate wildfires at northern latitudes, J. Geophys. Res., 105, 26871-26890, 2000.

Leung, F. T., Logan, J., and Diner, D. J.: The height of lofted biomass burning plumes over Alaska during the 2004 ICARTT period, Eos Trans. AGU, 87, Fall Meet. Suppl., Abstr. A51C0099, 2006.

Lohmann, U., Feichter, J., Chuang, C. C., and Penner, J. E.: Prediction of the number of cloud droplets in the ECHAM GCM, J. Geophys. Res., 104, 9169-9198, 1999.

Martins, J. V., Artaxo, P., Hobbs, P. V., Liousse, C., Cachier, H., Kaufman, Y., and Plana-Fattori, A.: Particle size distributions, elemental compositions, carbon measurements, and optical propreties of smoke from biomass burning in the Pacific Northwest of the United States, in: Global Biomass Burning and Global Change, edited by: Levine, J. S., MIT press, Cambridge, MA, 716-732, 1996.

Mattis, I., Ansmann, A., Wandinger, U., and Müller, D.: Unexpectedly high aerosol load in the free troposphere over central Europe in spring/summer 2003, Geophys. Res. Lett., 30, 2178, doi:10.1029/2003GL018442, 2003.

Methven, J., Arnold, S. R., O'Connor, F. M., Barjat, H., Dewey, K., Kent, J., and Brough, N.: Estimating photochemically produced ozone through a domain using flight data and a Lagrangian model, J. Geophys. Res., 108, 4271, doi:1029/2002JD002955, 2003.

Methven, J., Arnold, S. R., Stohl, A., et al.: Establishing Lagrangian connections between observations within air masses crossing the Atlantic during the International Consortium for Atmospheric Research on Transport and Transformation experiment, J. Geophys. Res., 111, D23S62, doi:10.1029/2006JD007540, 2006.

Minikin, A., Petzold, A., Fiebig, M., Hendricks, J., and Schröder, F.: Aerosol properties measured in situ in the free troposphere and tropopause region at midlatitudes, J. Aerosol Sci., Abstracts of the European Aerosol Conference 2003, S1155-S1156, 2003.
Morris, G. A., Hersey. S. , Thompson, A. M., et al.: Alaskan and Canadian forest fires exacerbate ozone pollution over Houston, Texas, on 19 and 20 July 2004, J. Geopyhs Res., 111, D24S03, doi:10.1029/2006JD007090, 2006.

Müller, D., Mattis, I., Wandinger, U., Ansmann, A., Althausen, D., and Stohl, A.: Raman lidar observations of aged Siberian and Canadian forest fire smoke in the free troposphere over Germany in 2003: Microphysical particle characterization, J. Geophys. Res., 110, D17201, doi:10.1029/2004JD005756, 2005.

Müller, D., Mattis, I., Ansmann, A., Wandinger, U., Ritter, C., and Kaiser, D.: Multiwavelength Raman lidar observations of particle growth during long-range transport of forest-fire smoke in the free troposphere, Geophys. Res. Lett., 34, L05803, doi:10.1029/2006GL027936, 2007.

Niemi, J.V., Tervahattu, H., Vehkamäki, H., Martikainen, J., Laakso, L., Kulmala, M., Aarnio, P., Koskental, T., Sillanpää, M., and Makkonen, U.: Characterisation of aerosol particle episodes in Finland caused by wildfires in Eastern Europe, Atmos. Chem. Phys., 5, 2299-2310, 2005,

http://www.atmos-chem-phys.net/5/2299/2005/.

Nyeki, S., Kalberer, M., Colbeck, I., De Wekker, S., Furger, M., Gäggeler, H.W., Kossmann, M., Lugauer, M., Steyn, D., Weingartner, E., Wirth, M., and Baltensperger, U.: Convective boundary layer evolution to $4 \mathrm{~km}$ a.s.l. over high-alpine terrain: Airborne lidar observations in the Alps, Geophys. Res Lett., 27, 689-692, 2000.

Nyeki, S., Eleftheriadis, K., Baltensperger, U., Colbeck, I., Fiebig, M., Fix, A., Kiemle, C., Lazaridis, M., and Petzold, A.: Airborne Lidar and in-situ aerosol observations of an elevated layer leeward of the European Alps and Apennines, Geophys. Res. Lett., 29, L1852, doi:10.1029/2002GL014897, 2002.

Park, R. J., Jacob, D. J., Palmer, P. I., Clarke, A. D., Weber, R. J., Zondlo, M. A., Eisele, F. L., Bandy, A. R., Thornton, D. C., Sachse, G. W., and Bond, T. C.: Export efficiency of black carbon aerosol in continental outflow: Global implications, J. Geophys. Res., 110, D11205, doi:10.1029/2004JD005432, 2005.

Petzold, A., Fiebig, M., Flentje, H., Keil, A., Leiterer, U., Stifter, A., Wendisch, M., and Wendling, P.: Vertical variability of aerosol properties observed at a continental site during LACE 98, J. Geophys. Res., 107, 8128, doi:10.1029/2001JD001043, 2002.

Petzold, A. and Schönlinner, M.: Multi-angle absorption photometry - a new method for the measurement of aerosol light absorption and atmospheric black carbon, J. Aerosol Sci., 35, 421-441, 2004.

Petzold, A., Schloesser, H., Sheridan, P.J., Arnott, W. P., Ogren, J. A., and Virkkula, A.: Evaluation of multi-angle absorption photometry for measuring aerosol light absorption, Aerosol Sci. Tech., 39, 40-51, 2005.

Pfister, G. G., Emmons, L. K., Hess, P. G., et al.: Ozone production from the 2004 North American boreal fires, J. Geophys. Res., 111, D24S07, doi:10.1029/2006JD007695, 2006.

Radke, L. F., Hegg, D. A., Hobbs, P. V., Nance, J. D., Lyons, J. H., Laursen, K. K., Weiss, R. E., Riggan, P. J., and Ward, D. E.: Particulate and trace gas emissions from large biomass fires in North America, in: Global Biomass Burning: Atmospheric, Climatic, and Biospheric Implications, edited by: Levine, J. S., MIT press, Cambridge, MA, 209-224, 1991.

Raes, F., van Dingenen, R., Vignati, E., Wilson, J., Putaud, J.-P., Seinfeld, J. H., and Adams, P.: Formation and cycling of aerosols in 
the global atmosphere, Atmos. Environ., 34, 4215-4240, 2000.

Rasch, P. J. and Williamson, D. L.: Computational aspects of moisture transport in global models of the atmosphere, Q. J. R. Meteor. Soc., 116, 1071-1090, 1990.

Real, E., Law, K., Weinzierl, B., Fiebig, M., Petzold, A., Wild, O., Arnold, S., Huntrieser, H., Stohl, A., and Schlager, H.: Processes influencing $\mathrm{O}_{3}$ levels in Alaskan forest fire plumes during long range transport over the North Atlantic, J. Geophys. Res., 112, D10S41, doi:10.1029/2006JD007576, 2007.

Reid, J. S., Koppmann, R., Eck, T. F., and Eleuterio, D. P.: A review of biomass burning emissions part II: intensive physical properties of biomass burning particles, Atmos. Chem. Phys., 5, 799825, 2005a.

Reid, J. S., Eck, T. F., Christopher, S. A., Koppmann, R., Dubovnik, O., Eleuterio, D. P., Holben, B. N., Reid, E. A., and Zhang, J.: A review of biomass burning emissions part III: intensive optical properties of biomass burning particles, Atmos. Chem. Phys., 5, 827-849, 2005b.

Reischl, G. P.: The relationship between input and output aerosol characteristics for an ideal differential mobility analyser particle standard, J. Aerosol Sci., 22, 297-312, 1991.

Robock, A.: Surface cooling due to forest fire smoke, J. Geophys. Res., 96, 20 869-20 878, 1991.

Röckner, E., Arpe, K., Bengtsson, L., Christoph, M., Claussen, M., Dümenil, L., Esch, M., Giorgetta, M., Schlese, U., and Schulzweida, U.: The atmospheric general circulation model ECHAM-4: Model description and simulation of present-day climate, Max Planck Institute for Meteorology, Report No. 218, Hamburg, Germany, ISSN 0937-1060, 1996.

Rosenfeld, D.: Suppression of rain and snow by urban and industrial air pollution, Science, 287, 1793-1796, 2000.

Sato, M., Hansen, J., Koch, D., Lacis, A., Ruedy, R., Dubovik, O., Holben, B., Chin, M., and Novakov, T.: Global atmospheric black carbon inferred from AERONET, Proc. Nat. Academy of Sci. (PNAS), 100, 6319-6324, 2003.

Schröder, F. P. and Ström, J.: Aircraft measurements of sub micrometer aerosol particles $(>7 \mathrm{~nm})$ in the midlatitude free troposphere and tropopause region, Atmos. Res., 44, 333-356, 1997.

Schröder, F., Kärcher, B., Petzold, A., and Fiebig, M.: Aerosol states in the free troposphere at northern midlatitudes, J. Geophys. Res., 107, LAC 8-1-LAC 8-8, doi:10.1029/2000JD000194, 2002.

Schwarz, J. P., Gao, R. S., Fahey, D. W., Thomson, D. S., Watts, L. A., Wilson, J. C., Reeves, J.M., Darbeheshti, M., Baumgardner, D. G., Kok, G. L., Chung, S. H., Schulz, M., Hendricks, J., Lauer, A., Kärcher, B., Slowik, J. G., Rosenlof, K. H., Thompson, T. L., Langford, A. O., Loewenstein, M., and Aikin, K. C.: Single-particle measurements of midlatitude black carbon and light-scattering aerosols from the boundary layer to the lower stratosphere, J. Geophys. Res., 111, D16207, doi:10.1029/2006JD007076, 2006.

Sheridan, P. J., Arnott, W. P., Ogren, J. A., Andrews, E., Atkinson, D. B., Covert, D. S., Moosmüller, H., Petzold, A., Schmidt, B., Strawa, A. W., Varma, R., and Virkkula, A.: The Reno Aerosol Optics Study: Overview and Summary of Results, Aerosol Sci. Tech., 39, 1-16, 2005.
Slowik, J. G., Cross, E. S., Han, J.-H., Davidovits, P., Onasch, T. B., Jayne, J. T., Williams, L. R., Canagaratna, M. R., Worsnop, D. R., Chakrabarty, R. K., Moosmüller, H., Arnott, W. P., Schwarz, J. P., Gao, R.-S., Fahey, D. W., Kok, G. L., and Petzold, A.: An Inter-Comparison of Instruments Measuring Black Carbon Content of Soot Particles, Aerosol Sci. Technol., 41, 295-314, doi:10.1080/02786820701197078, 2007.

Spichtinger, N., Damoah, R., Eckhardt, S., Forster, C., James, P., Beirle, S., Marbach, T., Wagner, T., Novelli, P. C., and Stohl, A.: Boreal forest fires in 1997 and 1998: a seasonal comparison using transport model simulations and measurement data, Atmos. Chem. Phys., 4, 1857-1868, 2004, http://www.atmos-chem-phys.net/4/1857/2004/.

Stohl, A., Hittenberger, M., and Wotawa, G.: Validation of the Lagrangian particle dispersion model FLEXPART against large scale tracer experiment data, Atmos. Environ., 32, 4245-4264, 1998.

Stohl, A., Forster, C., Eckhardt, S., Spichtinger, N., Huntrieser, H., Heland, J., Schlager, H., Wilhelm, S., Arnold, F., and Cooper, O.: A backward modeling study of intercontinental pollution transport using aircraft measurements, J. Geophys. Res., 108, 4370, doi:10.1029/2002JD002862, 2003.

Stohl, A., Forster, C., Frank, A., Seibert, P., and Wotawa, G.: Technical Note : The Lagrangian particle dispersion model FLEXPART version 6.2, Atmos. Chem. Phys., 5, 2461-2474, 2005, http://www.atmos-chem-phys.net/5/2461/2005/.

Stohl, A., Andrews, B., Burkhart, J.F., Fortser, C., Kowal, D., Lunder, C., Mefford, T., Ogren, J.A., Sharma, S., Spichtinger, N., Stebel, K., Stone, R., Ström, J., Torseth, K., and Wehrli, C.: PanArctic enhancements of light absorbing aerosol concentrations due to North American boreal forest fires during summer 2004, J. Geophys. Res., 111, D22214, doi:10.1029/2006JD007216, 2006

Streets, D. G., Bond, T. C., and Jang, C.: On the future of carbonaceous aerosol emissions, J. Geophys. Res., 109, D24212, doi:10.1029/2994JD004902, 2004.

Turquety, S., Logan, J. A., Jacob, D. J., et al: High temporal resolution inverse modelling of $\mathrm{CO}$ emissions from North American boreal fires and their injection height during the summer 2004, Eos Trans. AGU, 87, Fall Meet. Suppl., Abstract A53G-04, 2006.

Turquety, S., Logan, J. A., Jacob, D. J., et al.: Inventory of boreal fire emissions for North America in 2004: Importance of peat burning and pyroconvective injection, J. Geophys. Res., 112, D12S03, doi:10.1029/2006JD007281, 2007.

van der Werf, G., Randerson, J. T., Collatz, G. J., Giglio, L., Kasibhatta, P. S., Arellano Jr., A. F., Olsen, S. C., and Kasischke, E. S.: Continental-scale partitioning of fire emissions during the 1997 to $2001 \mathrm{El}$ Niño/La Niña period, Science, 303, 73-76, 2004.

van der Werf, G, Randerson, J. T., Giglio, L., Collatz, G. J., Kasibhatta, P. S., Arellano Jr., A. F.: Interannual variability of global biomass burning emissions from 1997 to 2004, Atmos. Chem. Phys., 6, 3423-3441, 2006,

http://www.atmos-chem-phys.net/6/3423/2006/. 